\title{
Bicarbonate transport of airway surface epithelia in luminally perfused mice bronchioles
}

\author{
Libin Liu', Akiko Yamamoto ${ }^{1}$, Makoto Yamaguchi ${ }^{1}$, Itsuka Taniguchi ${ }^{1}$, Nao Nomura', Miyuki Nakakuki ${ }^{1}$, \\ Yuka Kozawa' ${ }^{1}$, Tomoya Fukuyasu ${ }^{1}$, Mayuko Higuchi ${ }^{1}$, Erina Niwa ${ }^{1}$, Tsutomu Tamada ${ }^{2}$ and Hiroshi Ishiguro ${ }^{1,3^{*}}$ (D)
}

\begin{abstract}
$\mathrm{HCO}_{3}{ }^{-}$secretion in distal airways is critical for airway mucosal defense. $\mathrm{HCO}_{3}{ }^{-} / \mathrm{H}^{+}$transport across the apical membrane of airway surface epithelial cells was studied by measuring intracellular $\mathrm{pH}$ in luminally microperfused freshly dissected mice bronchioles. Functional studies demonstrated that CFTR, ENaC, $\mathrm{Cl}^{-}-\mathrm{HCO}_{3}{ }^{-}$exchange, $\mathrm{Na}^{+}-\mathrm{H}^{+}$ exchange, and $\mathrm{Na}^{+}-\mathrm{HCO}_{3}{ }^{-}$cotransport are involved in apical $\mathrm{HCO}_{3}{ }^{-} / \mathrm{H}^{+}$transport. RT-PCR of isolated bronchioles detected fragments from Cftr, $a, \beta$, $\gamma$ subunits of ENaC, Ae2, Ae3, NBCe1, NBCe2, NBCn1, NDCBE, NBCn2, Nhe1, Nhe2, Nhe4, Nhe5, SIc26a4, SIc26a6, and SIc26a9. We assume that continuous decline of intracellular pH following alkaline load demonstrates time course of $\mathrm{HCO}_{3}{ }^{-}$secretion into the lumen which is perfused with a $\mathrm{HCO}_{3}{ }^{-}$-free solution. Forskolin-stimulated $\mathrm{HCO}_{3}{ }^{-}$secretion was substantially inhibited by luminal application of $\mathrm{CFTR}_{\text {inh }}{ }^{-172}(5 \mu \mathrm{M}), \mathrm{H}_{2}$ DIDS $(200 \mu \mathrm{M})$, and amiloride $(1 \mu \mathrm{M})$. In bronchioles from a cystic fibrosis mouse model, basal and acetylcholine-stimulated $\mathrm{HCO}_{3}{ }^{-}$secretion was substantially impaired, but forskolin transiently accelerated $\mathrm{HCO}_{3}{ }^{-}$secretion of which the magnitude was comparable to wild-type bronchioles. In conclusion, we have characterized apical $\mathrm{HCO}_{3}{ }^{-} / \mathrm{H}^{+}$transport in native bronchioles. We have demonstrated that CAMP-mediated and $\mathrm{Ca}^{2+}$-mediated pathways are involved in $\mathrm{HCO}_{3}{ }^{-}$ secretion and that apical $\mathrm{HCO}_{3}{ }^{-}$secretion is largely mediated by CFTR and $\mathrm{H}_{2} \mathrm{DIDS}$-sensitive $\mathrm{Cl}^{-}-\mathrm{HCO}_{3}{ }^{-}$exchanger, most likely SIc26a9. The impairment of $\mathrm{HCO}_{3}{ }^{-}$secretion in bronchioles from a cystic fibrosis mouse model may be related to the pathogenesis of early lung disease in cystic fibrosis.
\end{abstract}

Keywords: Distal airway, $\mathrm{HCO}_{3}{ }^{-}$secretion, Bronchiole, Microperfusion, Surface epithelial cells, Intracellular pH

\section{Introduction}

The airway surface liquid (ASL) is a thin layer of fluid covering the luminal surface of airway epithelium. The ASL is composed of inner periciliary liquid layer (PCL) and outer single-layer thin mucus. Proper volume/depth, viscosity, and $\mathrm{pH}$ of ASL are required for efficient mucociliary clearance and antimicrobial activity $[11,38,47]$.

It is widely accepted that the volume/depth of PCL is determined by $\mathrm{Cl}^{-}$secretion via cystic fibrosis transmembrane conductance regulator (CFTR) and $\mathrm{Ca}^{2+}$-activated

*Correspondence: ishiguro@htc.nagoya-u.ac.jp

${ }^{3}$ Research Center of Health, Physical Fitness, and Sports, Nagoya University, Furo-cho E5-2 (130), Chikusa-ku, Nagoya 464-8601, Japan

Full list of author information is available at the end of the article
$\mathrm{Cl}^{-}$channel $(\mathrm{CaCC})$ and $\mathrm{Na}^{+}$absorption via epithelial $\mathrm{Na}^{+}$channel $(\mathrm{ENaC})$ [30,33]. In proximal airways, $\mathrm{Cl}^{-}$secretion is mostly derived from serous cells of submucosal glands $[5,8,17]$. In distal airways, submucosal glands are absent $[10,35]$ and concurrent $\mathrm{Cl}^{-}$secretion and $\mathrm{Na}^{+}$absorption was observed in surface epithelial cells [44]. Loss of CFTR function due to severe pathogenic variants in both alleles of the CFTR gene causes cystic fibrosis (CF). The initial event of CF lung disease is characterized by low PCL volume, which is thought to be achieved by defective CFTR-mediated $\mathrm{Cl}^{-}$secretion and abnormally elevated $\mathrm{Na}^{+}$absorption via $\mathrm{ENaC}$ [33].

Evidence has accumulated to indicate that $\mathrm{HCO}_{3}{ }^{-}$ transport is important in airway mucosal defense. $\mathrm{HCO}_{3}{ }^{-}$ concentration affects physical properties of mucus $[4,39]$ original author(s) and the source, provide a link to the Creative Commons licence, and indicate if changes were made. The images or other third party material in this article are included in the article's Creative Commons licence, unless indicated otherwise in a credit line to the material. If material is not included in the article's Creative Commons licence and your intended use is not permitted by statutory regulation or exceeds the permitted use, you will need to obtain permission directly from the copyright holder. To view a copy of this licence, visit http://creativecommons.org/licenses/by/4.0/. 
and mucociliary transport in ex vivo pig trachea under acetylcholine $(\mathrm{ACh})$ stimulation was more dependent on $\mathrm{HCO}_{3}{ }^{-}$secretion than $\mathrm{Cl}^{-}$secretion [13]. ASL pH in vivo newborn CF pigs was more acidic compared to wild-type and the impaired bacterial-killing activity of CF ASL was rescued by adding $\mathrm{NaHCO}_{3}$ [38]. Cellular mechanisms for $\mathrm{HCO}_{3}{ }^{-}$transport in airways have been studied using cultured human nasal epithelial cells [36, 37] and Calu-3 cells, a model of serous cells of submucosal glands [20, 25, 28]. However, $\mathrm{HCO}_{3}{ }^{-}$transport in distal airways/ bronchioles is not well understood. ASL pH was more alkaline in lower airways than in upper airways in human [34]. Thus, a balance of $\mathrm{HCO}_{3}{ }^{-}$and $\mathrm{H}^{+}$secretion may shift to $\mathrm{HCO}_{3}{ }^{-}$secretion in distal airways.

Distal airways contribute to $85-90 \%$ of the total epithelial surface area of conducting airways $[10,50]$. Moreover, mucus plugging and obstruction of bronchioles are among the earliest events of CF lung disease, suggesting that regulation of epithelial ion transport in distal airways is critical for normal lung physiology [46]. However, the assessment of ion transport in distal airways/bronchioles has been limited because of the small size, complex anatomy and relative inaccessibility of structures [10]. Measurement of transmembrane potential in sheep, porcine, and human bronchioles identified $\mathrm{Na}^{+}$and $\mathrm{Cl}^{-}$ conductive pathways $[2,6,9]$. Aquaporin-mediated transepithelial water permeability was identified in guinea pig bronchioles [18]. Measurement of transepithelial potentials by a capillary-Ussing chamber revealed concurrent fluid secretion and absorption and $\mathrm{HCO}_{3}{ }^{-}$secretion in human bronchioles [45]. However, characteristics and cellular mechanisms of $\mathrm{HCO}_{3}{ }^{-}$transport in distal airways/bronchioles have not been fully investigated.

In the present study, $\mathrm{HCO}_{3}{ }^{-}$transport in surface epithelial cells of native bronchioles was studied by measuring intracellular $\mathrm{pH}\left(\mathrm{pH}_{\mathrm{i}}\right)$ in luminally microperfused freshly dissected mice bronchioles. $\mathrm{HCO}_{3}{ }^{-}$transport in bronchioles from a CF mouse model was also studied.

\section{Methods}

\section{Ethics approval}

The study was approved by the Ethical Committee of Nagoya University on Animal Use for Experiment (approval No. M210457-003) and the Recombinant DNA Experiment Safety Committee of Nagoya University (approval No. 20-93).

\section{Isolation of bronchioles from mice lung}

A CF mouse model in which the F508del mutation was introduced in the mouse $C f t r$ with the C57BL/6J genetic background ( $\Delta \mathrm{F}$ mouse) [53] was purchased from the Jackson Laboratory (Bar Harbor, ME). $\Delta \mathrm{F}$ mice and their wild-type littermates were bled in Center for Research of
Laboratory Animals and Medical Research Engineering, Nagoya University. Mice (8-10 weeks of age) of either sex were suffocated with $\mathrm{CO}_{2}$. The thorax was opened and the ice-cold standard $\mathrm{HCO}_{3}{ }^{-}$-buffered solution was gently injected into the trachea to fill the lungs. The lungs were then removed and the segments of conducting bronchioles (the third or fourth branches, 150-180 $\mu \mathrm{m}$ in inner diameter) were micro-dissected using sharpened needles in the ice-cold standard $\mathrm{HCO}_{3}{ }^{-}$-buffered solution.

\section{Solutions}

The standard $\mathrm{HCO}_{3}{ }^{-}$-buffered solution contained $(\mathrm{mM})$ : $115 \mathrm{NaCl}, 5 \mathrm{KCl}, 1 \mathrm{CaCl}_{2}, 1 \mathrm{MgCl}_{2}, 10 \mathrm{D}$-glucose, and $25 \mathrm{mM} \mathrm{NaHCO}_{3}$, and was equilibrated with $95 \% \mathrm{O}_{2}-5 \%$ $\mathrm{CO}_{2}$. The $25 \mathrm{mM} \mathrm{HCO}{ }_{3}^{-}-0 \% \mathrm{CO}_{2}$ solution was gassed with $100 \% \mathrm{O}_{2}(\mathrm{pH}: \sim 7.8)$ and thus was nominally free of $\mathrm{CO}_{2}$. The standard Hepes-buffered solution contained (mM): $130 \mathrm{NaCl}, 5 \mathrm{KCl}, 1 \mathrm{CaCl}_{2}, 1 \mathrm{MgCl}_{2}, 10$ D-glucose, and $10 \mathrm{Na}$-Hepes, and was equilibrated with $100 \% \mathrm{O}_{2}$. The $\mathrm{Cl}^{-}$-free $\mathrm{HCO}_{3}{ }^{-}$-buffered solution contained (mM): $115 \mathrm{Na}$-gluconate, $2.5 \mathrm{~K}_{2} \mathrm{HPO}_{4}, 1 \mathrm{CaSO}_{4}$, $1 \mathrm{MgSO}_{4}, 10 \mathrm{D}$-glucose, and $25 \mathrm{mM} \mathrm{NaHCO}$, and was equilibrated with $95 \% \mathrm{O}_{2}-5 \% \mathrm{CO}_{2}$. The $\mathrm{Cl}^{-}$-free Hepesbuffered solution contained (mM): $130 \mathrm{Na}$-gluconate, 2.5 $\mathrm{K}_{2} \mathrm{HPO}_{4}, 1 \mathrm{CaSO}_{4}, 1 \mathrm{MgSO}_{4}, 10 \mathrm{D}$-glucose, and $10 \mathrm{Na}-$ Hepes, and was equilibrated with $100 \% \mathrm{O}_{2}$. The $\mathrm{Na}^{+}$-free $\mathrm{HCO}_{3}{ }^{-}$-buffered solution contained $\mathrm{N}$-methyl-D-glucamine (NMDG) in place of $\mathrm{NaCl}$, choline bicarbonate in place of $\mathrm{NaHCO}_{3}$, and $10 \mu \mathrm{M}$ atropine to prevent the possible activation of muscarinic receptors by choline. The $\mathrm{Na}^{+}$-free HEPES-buffered solution contained NMDG-Cl in place of $\mathrm{NaCl}$, and Hepes-acid in place of $\mathrm{Na}$-Hepes. In the $\mathrm{HCO}_{3}{ }^{-}$-buffered solution containing $20 \mathrm{mM} \mathrm{NH}_{4} \mathrm{Cl}$, the concentration of $\mathrm{NaCl}$ was reduced to maintain osmolarity. All solutions, except for the $25 \mathrm{mM}$ $\mathrm{HCO}_{3}{ }^{-}-0 \% \mathrm{CO}_{2}$ solution, were adjusted to $\mathrm{pH} 7.4$ at $37^{\circ} \mathrm{C}$.

\section{Microperfusion of isolated bronchioles}

The lumen of the isolated bronchiole segments was microperfused by applying a method to microperfuse isolated pancreatic ducts [22]. One end of bronchiole was cannulated for luminal microperfusion (Fig. 1a and b). The concentric pipette arrangement consisted of an outer holding pipette, an inner perfusion pipette, and a silica inner capillary for exchange of solutions. The combination of inner silica capillary and waste line enables rapid exchange of luminal solutions. The lumen was perfused at $20-30 \mu \mathrm{l} / \mathrm{min}$ while the bath was perfused at $3 \mathrm{ml} / \mathrm{min}$ and maintained at $37{ }^{\circ} \mathrm{C}$. The luminal perfusate leaving the other end of the bronchiole was diluted and washed away by the much greater flow of solution 

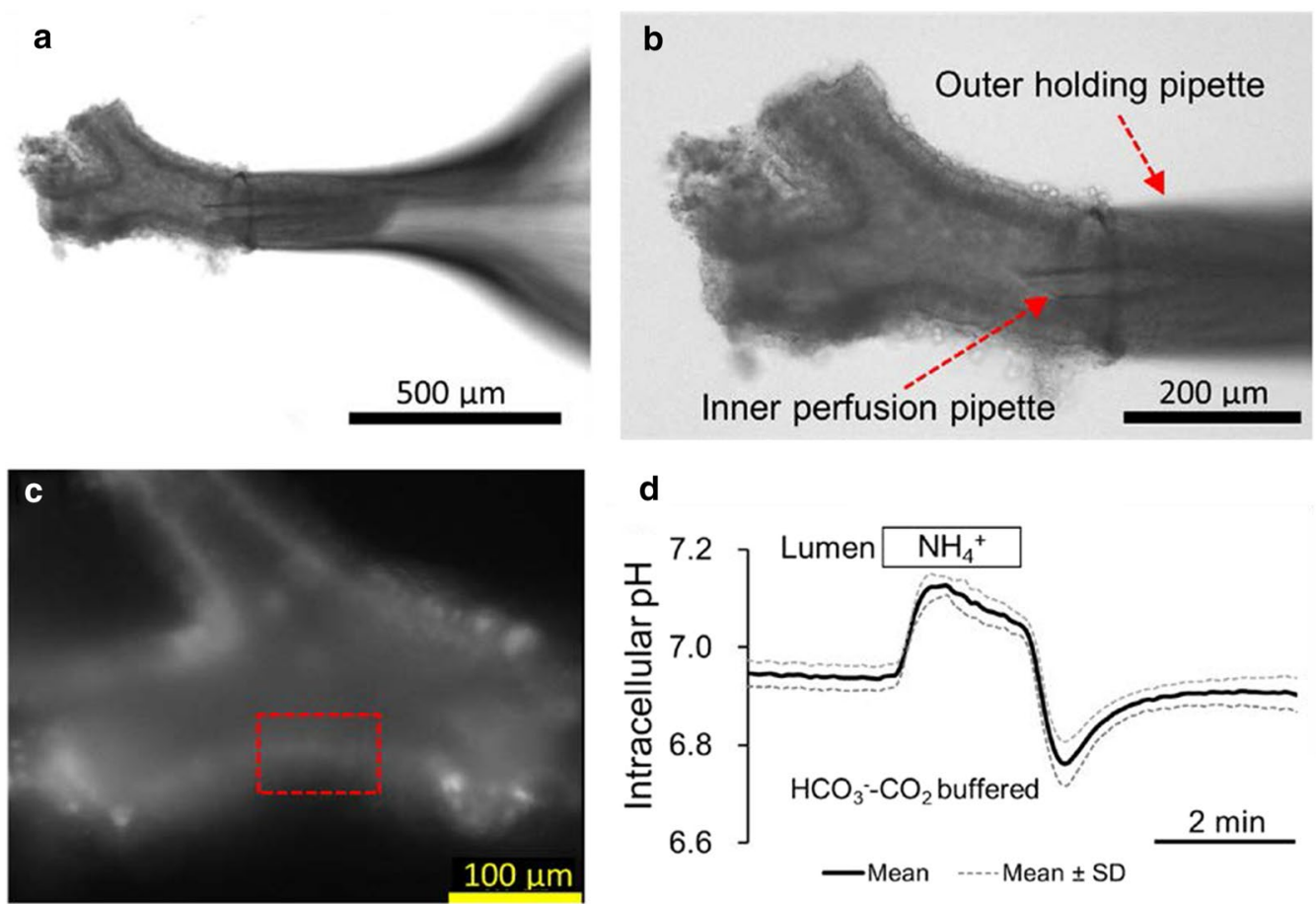

Fig. 1 Luminal microperfusion of an isolated bronchiole and measurement of intracellular $\mathrm{pH}$. $\mathbf{a}, \mathbf{b}$ The proximal end of an isolated bronchiole (inner diameter: $150 \mu \mathrm{m}$ ) is held and cannulated for luminal microperfusion $(20-30 \mu \mathrm{l} / \mathrm{min})$. The representative bronchiole is bifurcated. The luminal perfusate leaving the distal end of the bronchiole is diluted and washed away by the flow $(\sim 3 \mathrm{ml} / \mathrm{min})$ of solution through the bath. $\mathrm{c}$ Fluorescence of BCECF in surface epithelial cells lining the bronchiole. Small regions of the surface epithelium are selected (such as a rectangle) and the intracellular $\mathrm{pH}\left(\mathrm{pH}_{\mathrm{i}}\right)$ is estimated by microfluorometry at $37^{\circ} \mathrm{C} . \mathbf{d}$ Isolated bronchioles were bilaterally perfused with the standard $\mathrm{HCO}_{3}{ }^{-}$-buffered solution and $\mathrm{NH}_{4} \mathrm{Cl}(20 \mathrm{mM})$ was applied to the lumen. Time course changes of $\mathrm{pH}_{\mathrm{i}}$ are shown as means $\pm \mathrm{SD}$ of 5 experiments

through the bath, which prevented the luminal perfusate from gaining access to the basal surface of the bronchiole.

\section{Measurement of intracellular $\mathrm{pH}$ of bronchiole surface epithelium}

The intracellular $\mathrm{pH}\left(\mathrm{pH}_{\mathrm{i}}\right)$ in the epithelial cells was estimated by microfluorometry using the $\mathrm{pH}$-sensitive fluoroprobe 2,7'-bis-(2-carboxyethyl)-5(6)-carboxyfluorescein (BCECF). After cannulating a bronchiole for luminal microperfusion, the epithelial cells were loaded with BCECF by perfusing the lumen with a solution containing the acetoxymethyl ester BCECF-AM $(5 \mu \mathrm{M})$ for $10 \mathrm{~min}$. Small regions of the bronchiole surface epithelium (Fig. 1c) were illuminated alternately at 430 and $480 \mathrm{~nm}$ and fluorescence was measured at $530 \mathrm{~nm}\left(\mathrm{~F}_{430}\right.$ and $\left.\mathrm{F}_{480}\right)$. Values of $\mathrm{pH}_{\mathrm{i}}$ were calculated from the $\mathrm{F}_{480} /$ $\mathrm{F}_{430}$ ratio after correction for the endogenous tissue fluorescence measured prior to loading with BCECF. Calibration data were obtained by the high $\mathrm{K}^{+}$-nigericin technique [36, 48].

\section{Reverse transcriptase-polymerase chain reaction}

Messenger RNA expression of several ion transporters and channels was examined in isolated bronchioles and tracheal mucosa by polymerase chain reaction (PCR) (Table 1). Primers were derived from published sequences with GenBank accession numbers. The PCR protocol was: $96{ }^{\circ} \mathrm{C}, 25 \mathrm{~s} ; 60{ }^{\circ} \mathrm{C}, 30 \mathrm{~s} ; 72{ }^{\circ} \mathrm{C}, 40 \mathrm{~s} ; 35$ cycles. Templates for positive controls were complementary DNAs (cDNAs) prepared from lung, kidney, heart, colonic mucosa, brain and stomach mucosa. Glyceraldehyde-3-phosphate dehydrogenase (GAPDH)-specific primers (452 bp) were used for the positive controls.

\section{Materials}

BCECF-AM was obtained from Invitrogen (Carlsbad, USA); 4,4'-diisothiocyanatostilbene-2,2'-disulfonic acid disodium salt hydrate $\left(\mathrm{H}_{2} \mathrm{DIDS}\right)$ was from Molecular Probes (Eugene, USA); forskolin, amiloride, $\mathrm{CFTR}_{\mathrm{inh}}-172$ and other standard laboratory chemicals were from Sigma (St. Louis, USA). 
Table 1 Primer pairs used to amplify ion transporters and channels

\begin{tabular}{|c|c|c|c|c|}
\hline Name & Accession number & Primer & Sequence $\left(5^{\prime} \rightarrow 3^{\prime}\right)$ & Size (bp) \\
\hline \multirow[t]{2}{*}{$\mathrm{Cftr}$} & \multirow[t]{2}{*}{ NM_021050.2 } & Forward & (4070) atggaaagttgcagatgaggtt & \multirow[t]{2}{*}{399} \\
\hline & & Reverse & (4468) ctcatcttttccgaggagctaa & \\
\hline \multirow{2}{*}{$\begin{array}{l}\text { Slc26a3 } \\
\text { (Dra) }\end{array}$} & \multirow[t]{2}{*}{ NM_021353.3 } & Forward & (556) cctactttttcttgggcacatc & \multirow[t]{2}{*}{385} \\
\hline & & Reverse & (940) accgactccaggactttgaata & \\
\hline \multirow{2}{*}{$\begin{array}{l}\text { Slc26a4 } \\
\text { (Pendrin) }\end{array}$} & \multirow[t]{2}{*}{ NM_011867.4 } & Forward & (974) cggcatcctctccattatctac & \multirow[t]{2}{*}{465} \\
\hline & & Reverse & (1438) gccacaaaacaggagaaaaatc & \\
\hline \multirow[t]{2}{*}{ Slc26a6 (Pat1) } & \multirow[t]{2}{*}{ NM_134420.4 } & Forward & (2455) tgaaagagaagtgcggtgtaga & \multirow[t]{2}{*}{385} \\
\hline & & Reverse & (2839) ttcttcaggctcttaatgcaca & \\
\hline \multirow[t]{2}{*}{ Slc26a9 } & \multirow[t]{2}{*}{ NM_177243.4 } & Forward & (1457) cactgacccctactacctctgg & \multirow[t]{2}{*}{425} \\
\hline & & Reverse & (1881) tggttttcatgaagagggactt & \\
\hline \multirow[t]{2}{*}{$\mathrm{a}-\mathrm{ENaC}$} & \multirow[t]{2}{*}{ NM_011324.2 } & Forward & (1496) caggcgaattattctcagttcc & \multirow[t]{2}{*}{451} \\
\hline & & Reverse & (1946) ccttgggcttagggtagaagat & \\
\hline \multirow[t]{2}{*}{$\beta-E N a C$} & \multirow[t]{2}{*}{ NM_001272023.1 } & Forward & (1004) acatcggtcaggaggactatgt & \multirow[t]{2}{*}{282} \\
\hline & & Reverse & (1285) ggtcttggaaacaggaatgaag & \\
\hline \multirow[t]{2}{*}{$\gamma-\mathrm{ENaC}$} & \multirow[t]{2}{*}{ NM_011326.3 } & Forward & (709) gaagaaactggtgggatttcag & \multirow[t]{2}{*}{367} \\
\hline & & Reverse & (1075) gaaggggttgtactcatcttcg & \\
\hline \multirow[t]{2}{*}{ Slc4a2 (Ae2) } & \multirow[t]{2}{*}{ NM_001253892.1 } & Forward & (3298) aacccaagattcaggaagtcaa & 471 \\
\hline & & Reverse & (3768) tctcgttgtactcatccacacc & \\
\hline Slc4a3 (Ae3) & NM_001357149.1 & Forward & (1612) atgaccctgatgctaaggagaa & 393 \\
\hline & & Reverse & (2004) gaatcacaatgctaccatccaa & \\
\hline Slc4a4 (NBCe1) & NM_001136260.1 & Forward & (2206) aaaaccagtcgctattttccaa & 412 \\
\hline & & Reverse & (2617) gggcaatggagataacagtagc & \\
\hline Slc4a5 (NBCe2) & NM_001166067.1 & Forward & (1814) agcctcttatcatcctcagcag & 315 \\
\hline & & Reverse & (2128) tgtaggtggtgatgaagtcagg & \\
\hline Slc4a7 (NBCn1) & NM_001033270.2 & Forward & (676) accctatgtggcaactctgtct & 393 \\
\hline & & Reverse & (1068) ttttctctgcttcctccacttc & \\
\hline Slc4a8 (NDCBE) & NM_001347102.1 & Forward & (381) gtttgaagaggatgtggaggac & 434 \\
\hline & & Reverse & (814) gatccaccttgcttagatccac & \\
\hline Slc4a10 (NBCn2) & NM_001242378.1 & Forward & (2967) gtgcttcgtctctcaaaggaat & 445 \\
\hline & & Reverse & (3412) cacatggcagtctttgacattt & \\
\hline Slc9a1 (Nhe1) & NM_134647.4 & Forward & (951) gtgcctgatagcaggagagc & 202 \\
\hline & & Reverse & (1153) ccttgtccttggacagtgct & \\
\hline Slc9a2 (Nhe2) & NM_001033289.2 & Forward & (2088) gcacagtcttcgggaaagtc & 168 \\
\hline & & Reverse & (2256) gtccgagtcgctgctatttc & \\
\hline Slc9a3 (Nhe3) & NM_001081060.2 & Forward & (2046) acagaagcggaggaatagca & 199 \\
\hline & & Reverse & (2245) tatcaattcctgecccagag & \\
\hline Slc9a4 (Nhe4) & NM_177084.3 & Forward & (2084) gaggaacctgccaaaatcaa & 162 \\
\hline & & Reverse & (2246) ccacgtcttcaggagaaagc & \\
\hline Slc9a5 (Nhe5) & NM_001323971.2 & Forward & (970) ggacaggtgggaacagtttg & 182 \\
\hline & & Reverse & (1152) ggcatagagggcagagtgag & \\
\hline
\end{tabular}

\section{Statistics}

Data are presented as the means \pm SD unless otherwise indicated. Tests for statistically significant differences were made with Student's $t$-test.

\section{Results}

Isolated bronchioles from $\mathrm{CF}$ mice $(\Delta \mathrm{F} / \Delta \mathrm{F}$ mice) were used in experiments shown in Fig. 8. Isolated bronchioles from wild-type mice were used in the other experiments (Figs. 1, 2, 3, 4, 5, 6, 7). 

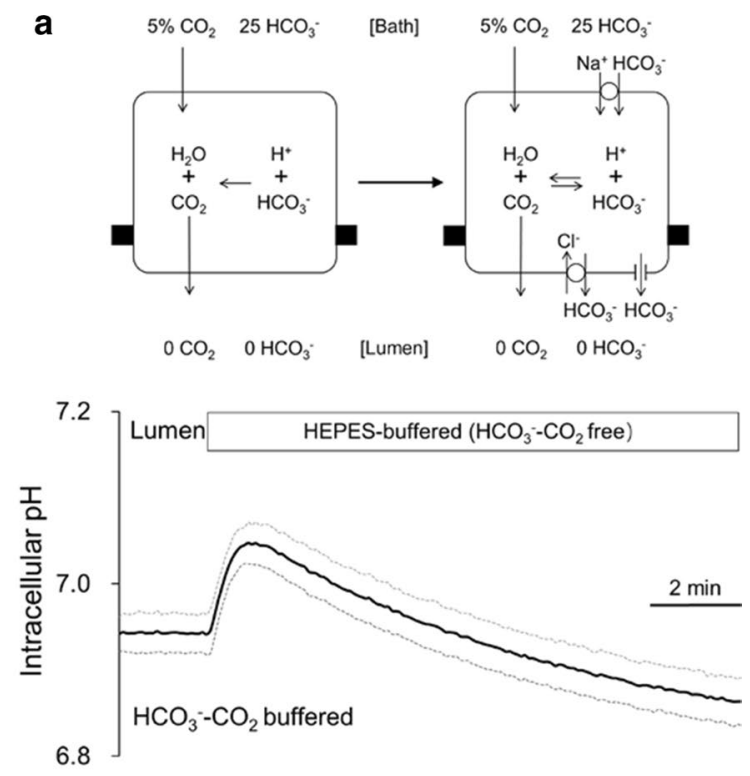

b

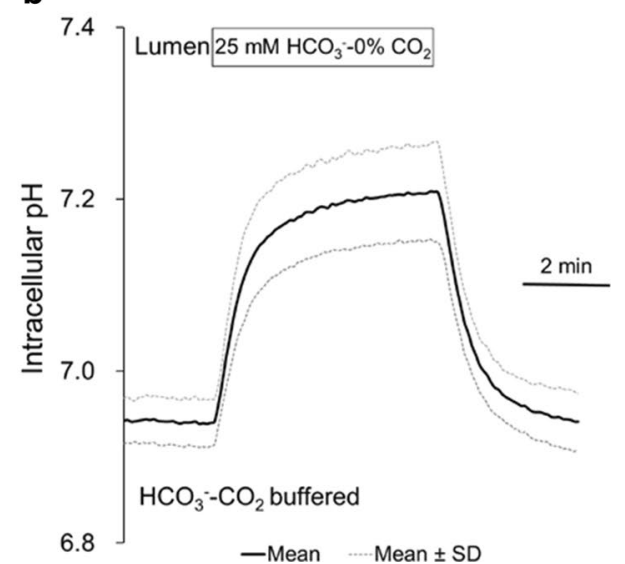

Fig. 2 Effects of luminal $\mathrm{HCO}_{3}{ }^{-}-\mathrm{CO}_{2}$ removal on $\mathrm{pH}_{\mathrm{i}}$ in bronchiole epithelial cells. a The experimental protocol used for the measurement of $\mathrm{HCO}_{3}{ }^{-}$efflux across the apical membrane of microperfused bronchioles. Isolated bronchioles were first bilaterally perfused with the standard $\mathrm{HCO}_{3}{ }^{-}$-buffered solution and the luminal perfusate was switched to the standard Hepes-buffered $\mathrm{HCO}_{3}{ }^{-}$ $\mathrm{CO}_{2}$-free solution. It was assumed that the transient alkalinization was due to $\mathrm{CO}_{2}$ diffusion out of the cell and the subsequent recovery was due to $\mathrm{HCO}_{3}{ }^{-}$efflux mostly across the apical membrane. Means \pm SD of 8 experiments. $\mathbf{b}$ Isolated bronchioles were first bilaterally perfused with the standard $\mathrm{HCO}_{3}{ }^{-}$-buffered solution and the luminal perfusate was switched to the solution which first contained $25 \mathrm{mM} \mathrm{HCO}_{3}{ }^{-}$ but which was equilibrated with $100 \% \mathrm{O}_{2}(\mathrm{pH}: \sim 7.8)$ and thus was nominally free of $\mathrm{CO}_{2}$. Means $\pm \mathrm{SD}$ of 8 experiments

\section{Basal $\mathrm{pH}_{\mathrm{i}}$ in bronchiole epithelial cells and the response} to luminal $\mathrm{NH}_{4}{ }^{+}$

When isolated bronchioles were bilaterally (bath and lumen) perfused with the standard $\mathrm{HCO}_{3}{ }^{-}$-buffered solution containing $25 \mathrm{mM} \mathrm{HCO}_{3}^{-}$and $5 \% \mathrm{CO}_{2}(\mathrm{pH} 7.4)$, basal $\mathrm{pH}_{\mathrm{i}}$ was $6.94 \pm 0.03(n=64$, mean $\pm \mathrm{SD})$. When isolated bronchioles were bilaterally perfused with the standard Hepes-buffered $\left(\mathrm{HCO}_{3}{ }^{-}-\mathrm{CO}_{2}\right.$-free) solution ( $\mathrm{pH}$ 7.4), basal $\mathrm{pH}_{\mathrm{i}}$ was $6.77 \pm 0.03(n=40)$. Basal $\mathrm{pH}_{\mathrm{i}}$ in the presence of $\mathrm{HCO}_{3}{ }^{-}-\mathrm{CO}_{2}$ was significantly $(p<0.01)$ higher compared to that in the absence of $\mathrm{HCO}_{3}{ }^{-}-\mathrm{CO}_{2}$. When $\mathrm{NH}_{4} \mathrm{Cl}$ $(20 \mathrm{mM})$ was applied to the lumen in the presence of $\mathrm{HCO}_{3}{ }^{-}-\mathrm{CO}_{2}, \mathrm{pH}_{\mathrm{i}}$ showed typical time-course changes by $\mathrm{NH}_{4}{ }^{+}$pulse [40]. Addition of $\mathrm{NH}_{4} \mathrm{Cl}$ caused quick alkalinization $\left(\mathrm{NH}_{3}\right.$ influx) followed by slower decline and removal of $\mathrm{NH}_{4} \mathrm{Cl}$ caused quick acidification $\left(\mathrm{NH}_{3}\right.$ efflux) followed by slower recovery to the baseline (Fig. 1d). This suggests that $\mathrm{H}^{+} / \mathrm{HCO}_{3}{ }^{-}$transport is active in this preparation.

\section{Effects of luminal $\mathrm{HCO}_{3}{ }^{-}-\mathrm{CO}_{2}$ removal on $\mathrm{pH}_{\mathrm{i}}$ in microperfused bronchioles}

When isolated bronchioles were first bilaterally perfused with the standard $\mathrm{HCO}_{3}{ }^{-}$-buffered solution and the luminal perfusate was switched to the standard Hepes-buffered $\left(\mathrm{HCO}_{3}{ }^{-}-\mathrm{CO}_{2}\right.$-free) solution (Fig. 2a), $\mathrm{pH}_{\mathrm{i}}$ quickly increased from $6.94 \pm 0.02$ to $7.05 \pm 0.02(n=8)$ and then gradually decreased towards a value $(6.86 \pm 0.03)$ lower than the baseline in $10 \mathrm{~min}$. To distinguish between the separate effects of removal of $\mathrm{CO}_{2}$ and $\mathrm{HCO}_{3}{ }^{-}$from the lumen, a solution was prepared which first contained $25 \mathrm{mM} \mathrm{HCO}_{3}{ }^{-}$but which was equilibrated with $100 \% \mathrm{O}_{2}$ ( $\mathrm{pH}: \sim 78$ ) and thus was nominally free of $\mathrm{CO}_{2}$. When the luminal perfusate was switched to the $25 \mathrm{mM} \mathrm{HCO}_{3}{ }^{-}-0 \%$ $\mathrm{CO}_{2}$ solution, $\mathrm{pH}_{\mathrm{i}}$ quickly increased to $7.21 \pm 0.06(n=8)$ and the alkalinization was sustained (Fig. 2b). Thus, the transient alkalinization and the subsequent recovery (acidification) by removal of luminal $\mathrm{HCO}_{3}^{-}-\mathrm{CO}_{2}$ was most likely due to $\mathrm{CO}_{2}$ diffusion of out of the cell followed by $\mathrm{HCO}_{3}{ }^{-}$efflux (Fig. 2a). Most of the $\mathrm{HCO}_{3}{ }^{-}$efflux was probably via the apical membrane due to the steep $\mathrm{HCO}_{3}{ }^{-}$ gradient between the cell and the lumen $\left(\mathrm{HCO}_{3}{ }^{-}\right.$concentration was close to zero). $\mathrm{H}^{+}$influx was not likely involved in the subsequent acidification because $\mathrm{Na}^{+}-\mathrm{H}^{+}$exchanger would work for $\mathrm{H}^{+}$extrusion in this condition.

\section{Effects of luminal application of forskolin, CFTR $_{\text {inh }}-172$, $\mathrm{H}_{2}$ DIDS, and amiloride on apical $\mathrm{HCO}_{3}{ }^{-}$efflux in bronchiole epithelial cells}

The mechanisms for $\mathrm{HCO}_{3}{ }^{-}$efflux across the apical membrane were examined using the protocol of Fig. 2a. After $\mathrm{HCO}_{3}{ }^{-}-\mathrm{CO}_{2}$ was removed from the luminal perfusate, forskolin $(5 \mu \mathrm{M})$, the activator of adenylate cyclase, was applied to the lumen as indicated (Fig. 3a). Stimulation with forskolin transiently accelerated the $\mathrm{pH}_{\mathrm{i}}$ decline by $97 \%(p<0.01)(n=8$, Fig. 3a and $\mathrm{f})$ of control (without forskolin stimulation: blue line in Fig. 3a). The late phase of $\mathrm{pH}_{\mathrm{i}}$ decline (at midpoint $\mathrm{pH}_{\mathrm{i}}$ of 6.95) was also accelerated by $47 \%(p<0.05)$ (Fig. $3 \mathrm{a}$ and $\mathrm{g})$ of control. The 
data suggest that elevation of intracellular cAMP activates $\mathrm{HCO}_{3}{ }^{-}$secretion in a biphasic manner: initial large response followed by sustained activation, in mice bronchiole epithelial cells.

CFTR $_{\text {inh }}-172(5 \mu \mathrm{M})$ and $\mathrm{H}_{2}$ DIDS $(200 \mu \mathrm{M})$ in the lumen inhibited the forskolin-stimulated transient $\mathrm{pH}_{\mathrm{i}}$ decline by $69 \%(n=8, p<0.01)$ (Fig. $3 \mathrm{~b}$ and $\left.\mathrm{f}\right)$ and $65 \%(n=8, p<0.01)$ (Fig. $3 \mathrm{c}$ and $\mathrm{f})$, respectively. Luminal CFTR $_{\text {inh }}-172$ and $\mathrm{H}_{2}$ DIDS also slowed down the late phase of $\mathrm{pH}_{\mathrm{i}}$ decline (at midpoint $\mathrm{pH}_{\mathrm{i}}$ of 6.95) by $54 \%(p<0.01)$ (Fig. $3 \mathrm{~b}$ and g) and 33\% $(p<0.05)$ (Fig. 3c and g), respectively. The data suggest that both CFTR and $\mathrm{H}_{2}$ DIDS-sensitive $\mathrm{HCO}_{3}{ }^{-}$transporter and/or $\mathrm{HCO}_{3}{ }^{-}$-permeable anion channel partly mediate cAMPstimulated $\mathrm{HCO}_{3}{ }^{-}$secretion. The forskolin-stimulated transient $\mathrm{pH}_{\mathrm{i}}$ decline in the presence of both CFTR $\mathrm{inh}-172$ and $\mathrm{H}_{2}$ DIDS (Fig. $3 \mathrm{~d}$ and $\mathrm{f}$ ) was significantly $(p<0.05)$ smaller compared to that in the presence of CFTR inh -172 or $\mathrm{H}_{2}$ DIDS alone (Fig. 3b, c, and f). The late-phase of $\mathrm{pH}_{\mathrm{i}}$ decline in the presence of both CFTR inh -172 and $\mathrm{H}_{2}$ DIDS (Fig. $3 \mathrm{~d}$ and g) was significantly $(p<0.05)$ slower compared to that in the presence of $\mathrm{H}_{2} \mathrm{DIDS}$ alone (Fig. 3c and $\mathrm{g}$ ).

Luminal application of $\mathrm{CFTR}_{\text {inh }}-172$ and $\mathrm{H}_{2}$ DIDS by themselves induced a transient small dip of $\mathrm{pH}_{\mathrm{i}}$ (Fig. $3 \mathrm{~b}$ and $\mathrm{c}$ ). The transient $\mathrm{pH}_{\mathrm{i}}$ dip largely disappeared when CFTR $_{\text {inh }}-172$ and $\mathrm{H}_{2}$ DIDS were simultaneously applied to the lumen (Fig. $3 \mathrm{~d}$ ). This suggests that CFTR and $\mathrm{H}_{2}$ DIDS-sensitive $\mathrm{HCO}_{3}{ }^{-}$transporter/channel compensate each other for apical $\mathrm{HCO}_{3}{ }^{-}$efflux. We speculate on the mechanisms as follows. CFTR inhibition would hyperpolarize the cell, which would induce transient $\mathrm{HCO}_{3}{ }^{-}$efflux via a $\mathrm{HCO}_{3}{ }^{-}$-permeable anion channel or an electrogenic $\mathrm{HCO}_{3}{ }^{-}$transporter (such as $1 \mathrm{Cl}^{-}-2 \mathrm{HCO}_{3}{ }^{-}$exchanger). If $\mathrm{H}_{2}$ DIDS-sensitive $\mathrm{HCO}_{3}$ - transport is electrogenic, luminal $\mathrm{H}_{2}$ DIDS would hyperpolarize the cell, which would induce transient $\mathrm{HCO}_{3}{ }^{-}$efflux via CFTR.

To examine the role of $\mathrm{ENaC}$ in $\mathrm{HCO}_{3}{ }^{-}$secretion, a relatively low concentration of amiloride $(1 \mu \mathrm{M})$ [32] was applied to the lumen. Amiloride $(1 \mu \mathrm{M})$ in the lumen inhibited the forskolin-stimulated transient $\mathrm{pH}_{\mathrm{i}}$ decline by $63 \%(n=8, p<0.01)$ (Fig. 3e and $\mathrm{f})$, but did not significantly affect the late phase of $\mathrm{pH}_{\mathrm{i}}$ decline (Fig. $3 \mathrm{e}$ and $\mathrm{g}$ ).
The data suggest that $\mathrm{ENaC}$ is involved in the regulation of $\mathrm{HCO}_{3}{ }^{-}$secretion. The transient dip of $\mathrm{pH}_{\mathrm{i}}$ by luminal amiloride (Fig. 3e) likely indicates apical $\mathrm{HCO}_{3}{ }^{-}$efflux which is accelerated by membrane hyperpolarization.

When isolated bronchioles were bilaterally perfused with the standard $\mathrm{HCO}_{3}{ }^{-}$-buffered solution, application of CFTR $_{\text {inh- }}-172(5 \mu \mathrm{M})$ to the lumen caused a transient increase of $\mathrm{pH}_{\mathrm{i}}$ by $0.022 \pm 0.003$ unit $(n=8$, data not shown). The $\mathrm{pH}_{\mathrm{i}}$ increase was not observed in the absence of $\mathrm{HCO}_{3}{ }^{-}-\mathrm{CO}_{2}$ and enhanced by $77 \%(p<0.05)$ by stimulation with forskolin $(5 \mu \mathrm{M})$ (data not shown). The data suggest that CFTR is involved in $\mathrm{HCO}_{3}{ }^{-}$secretion in a physiological condition.

\section{Effects of luminal $\mathrm{Cl}^{-}$removal on $\mathrm{pH}_{\mathrm{i}}$ in bronchiole epithelial cells}

To examine the activity of $\mathrm{Cl}^{-}-\mathrm{HCO}_{3}{ }^{-}$exchange in the apical membrane, effects of luminal $\mathrm{Cl}^{-}$removal on $\mathrm{pH}_{\mathrm{i}}$ were examined. When isolated bronchioles were bilaterally perfused with the standard Hepes-buffered $\mathrm{HCO}_{3}{ }^{-}-\mathrm{CO}_{2}$-free solution, removal of luminal $\mathrm{Cl}^{-}$(by replacement with gluconate) caused a slight decline of $\mathrm{pH}_{\mathrm{i}}$ (Fig. 4a and e). In contrast, when isolated bronchioles were bilaterally perfused with the standard $\mathrm{HCO}_{3}{ }^{-}$-buffered solution, luminal $\mathrm{Cl}^{-}$removal caused a reversible increase of $\mathrm{pH}_{\mathrm{i}}$ by $0.14 \pm 0.03$ unit $(n=8)$ over $\sim 4$ min period (Fig. $4 \mathrm{~b}$ and e), most likely due to influx of luminal $\mathrm{HCO}_{3}^{-}$in exchange for intracellular $\mathrm{Cl}^{-}$. When the activity of apical $\mathrm{Cl}^{-}-\mathrm{HCO}_{3}{ }^{-}$exchange is shown as the initial rate of $\mathrm{pH}_{\mathrm{i}}$ increase upon luminal $\mathrm{Cl}^{-}$removal, the activity is not affected by forskolin $(5 \mu \mathrm{M})$ in the lumen (Fig. $4 \mathrm{c}$ and e) and largely $(p<0.01)$ inhibited by $\mathrm{H}_{2}$ DIDS $(200 \mu \mathrm{M})$ in the lumen (Fig. $4 \mathrm{~d}$ and e). The data suggest that $\mathrm{H}_{2} \mathrm{DIDS}$-sensitive $\mathrm{Cl}^{-}-\mathrm{HCO}_{3}{ }^{-}$ exchanger is localized in the apical membrane.

\section{$\mathrm{Na}^{+}$-dependent $\mathrm{H}^{+}$extrusion across the apical membrane of bronchiole epithelial cells}

To examine whether $\mathrm{Na}^{+}-\mathrm{H}^{+}$exchanger (NHE) and $\mathrm{Na}^{+}-\mathrm{HCO}_{3}{ }^{-}$cotransporter (NBC) are localized in the apical membrane, luminal $\mathrm{Na}^{+}$-dependent $\mathrm{H}^{+}$extrusion was examined. In the absence of $\mathrm{HCO}_{3}{ }^{-}-\mathrm{CO}_{2}$, removal of luminal $\mathrm{Na}^{+}$(by replacement with NMDG) caused a continuous decline of $\mathrm{pH}_{\mathrm{i}}$ and restoration of $\mathrm{Na}^{+}$to the

\footnotetext{
(See figure on next page.)
}

Fig. 3 Effects of luminal application of forskolin, $\mathrm{CFTR}_{\text {inh }}{ }^{-172}, \mathrm{H}_{2} \mathrm{DIDS}$, and amiloride on apical $\mathrm{HCO}_{3}{ }^{-}$efflux. a-e Isolated bronchioles were first bilaterally perfused with the standard $\mathrm{HCO}_{3}{ }^{-}$-buffered solution and the luminal perfusate was switched to the standard $\mathrm{Hepes}^{-b u f f e r e d ~} \mathrm{HCO}_{3}{ }^{-}-$ $\mathrm{CO}_{2}$-free solution. After $\mathrm{HCO}_{3}{ }^{-}-\mathrm{CO}_{2}$ was removed from the luminal perfusate, forskolin $(5 \mu \mathrm{M})$ was applied to the lumen. Time course changes of $\mathrm{pH}_{\mathrm{i}}$ in the absence $(\mathbf{a})$ or presence of $\mathrm{CFTR}_{\text {inh }}{ }^{-172}(5 \mu \mathrm{M})$ in the lumen $(\mathbf{b}), \mathrm{H}_{2} \mathrm{DIDS}(200 \mu \mathrm{M})$ in the lumen $(\mathbf{c})$, both $\mathrm{CFTR}_{\text {inh }}{ }^{-172}(5 \mu \mathrm{M})$ and $\mathrm{H}_{2} \mathrm{DIDS}$ $(200 \mu \mathrm{M})$ in the lumen $(\mathbf{d})$, or amiloride $(1 \mu \mathrm{M})$ in the lumen $(\mathbf{e})$ are shown as means \pm SD of 8 experiments, respectively. The blue line in $\mathbf{a}$ indicates mean change of $\mathrm{pH}_{\mathrm{i}}$ without forskolin stimulation as a reference. $\mathbf{f}$ Early-phase $\mathrm{pH}_{\mathrm{i}}$ decline ( $\mathrm{pH}$ for $1 \mathrm{~min}$ ) just after forskolin stimulation. ${ }^{\#} p<0.01$ compared with control (without forskolin stimulation). ${ }^{*} p<0.01$ compared with forskolin alone. ${ }^{\circledR} p<0.05$. g Late-phase $p H_{i}$ decline $(\Delta p H / m i n$ at midpoint $\mathrm{pH}_{\mathrm{i}}$ of 6.95) under forskolin stimulation (red dashed lines in a-e). ${ }^{*} p<0.05$ compared with control (without forskolin stimulation). ${ }^{*} p<0.01$, ${ }^{* *} p<0.05$ compared with forskolin alone. ${ }^{{ }^{*}} p<0.01$ 

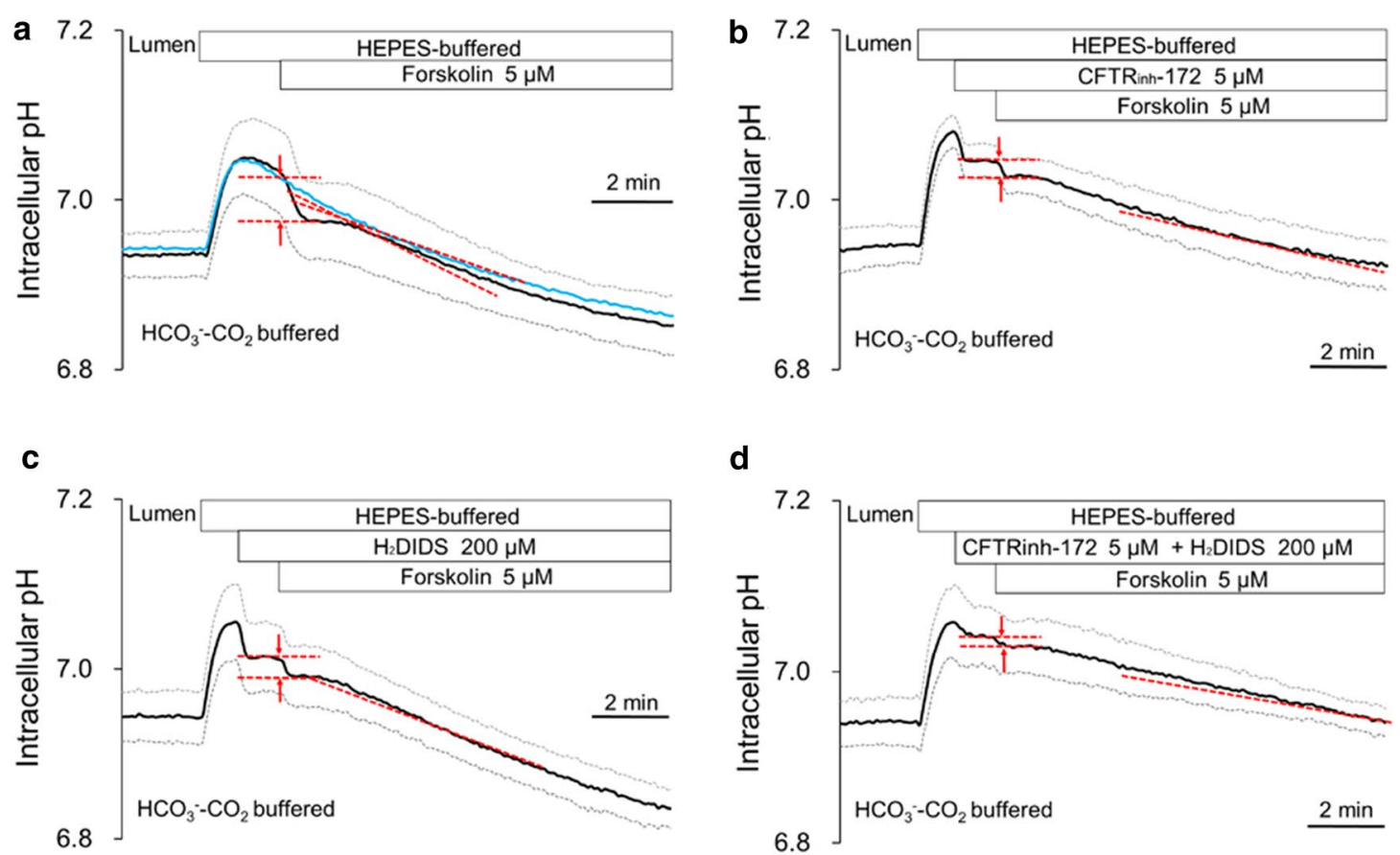

e

f
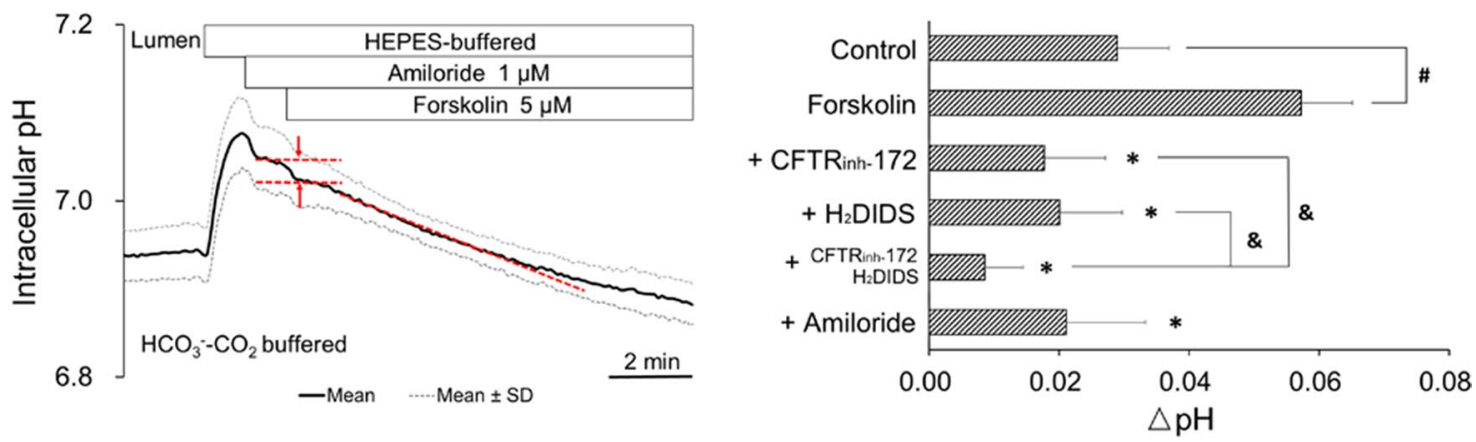

g

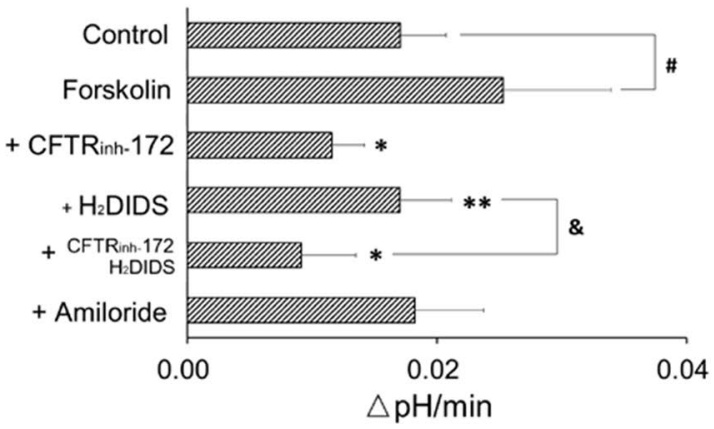

Fig. 3 (See legend on previous page.)

lumen caused a recovery (Fig. 5a). When the activity of luminal $\mathrm{Na}^{+}$-dependent $\mathrm{H}^{+}$extrusion is shown as the initial $\mathrm{pH}_{\mathrm{i}}$ increase $(\Delta \mathrm{pH}$ for $1 \mathrm{~min})$ upon restoration of luminal $\mathrm{Na}^{+}$, the activity was completely $(p<0.01)$ inhibited by amiloride $(100 \mu \mathrm{M})$ in the lumen (Fig. $5 \mathrm{~b}$ and 

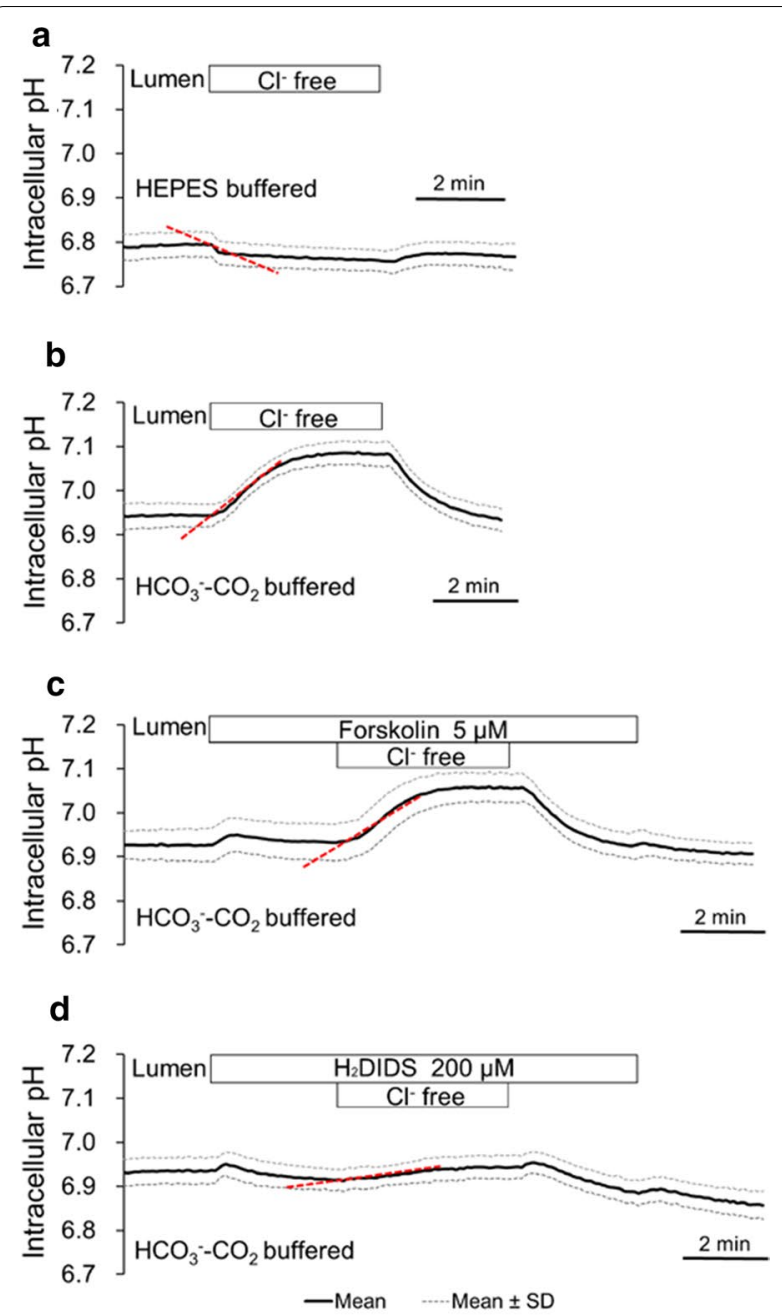

e

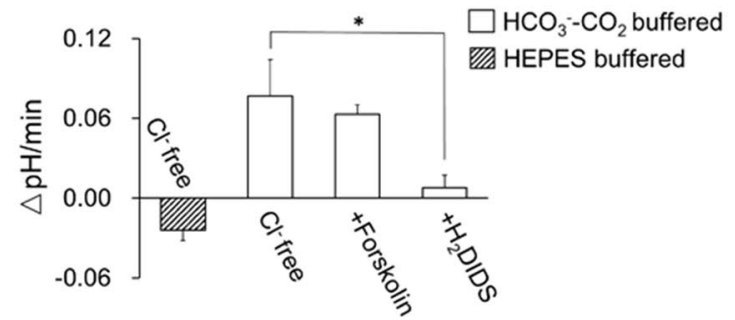

Fig. 4 Effects of luminal $\mathrm{Cl}^{-}$removal on $\mathrm{pH}_{\mathrm{i}}$ in bronchiole epithelial cells. a-d Isolated bronchioles were first bilaterally perfused with the standard Hepes-buffered $\mathrm{HCO}_{3}{ }^{-}-\mathrm{CO}_{2}$-free solution (a) or the standard $\mathrm{HCO}_{3}{ }^{-}$-buffered solution (b-d). Luminal $\mathrm{Cl}^{-}$was removed by replacement with gluconate in the absence $(\mathbf{a}, \mathbf{b})$ or presence of luminal forskolin $(5 \mu \mathrm{M})(\mathbf{c})$ or luminal $\mathrm{H}_{2} \mathrm{DIDS}(200 \mu \mathrm{M})(\mathbf{d})$. Time course changes of $\mathrm{pH}_{\mathrm{i}}$ are shown as means $\pm \mathrm{SD}$ of 8 experiments, respectively. $\mathbf{e}$ The activity of apical $\mathrm{Cl}^{-}-\mathrm{HCO}_{3}{ }^{-}$exchange is shown as the initial rate of $\mathrm{pH}_{\mathrm{i}}$ increase upon luminal $\mathrm{Cl}^{-}$removal (red dashed lines in $\mathbf{a}-\mathbf{d}$ ). ${ }^{*} p<0.01$ f). The data suggest that NHE is localized in the apical membrane.

The activity of luminal $\mathrm{Na}^{+}$-dependent $\mathrm{H}^{+}$extrusion in the presence of $\mathrm{HCO}_{3}{ }^{-}-\mathrm{CO}_{2}$ (Fig. $5 \mathrm{c}$ and $\mathrm{f}$ ) was significantly $(p<0.05)$ greater compared to that in the absence of $\mathrm{HCO}_{3}{ }^{-}-\mathrm{CO}_{2}$ (Fig. 5a and f), partially inhibited by amiloride $(100 \mu \mathrm{M})$ in the lumen (Fig. $5 \mathrm{~d}$ and $\mathrm{f}$ ), and completely inhibited by a combination of amiloride $(100 \mu \mathrm{M})$ and $\mathrm{H}_{2}$ DIDS $(200 \mu \mathrm{M})$ in the lumen (Fig. 5e and $f$ ). The data suggest that NBC is localized in the apical membrane.

\section{Effects of luminal amiloride on $\mathrm{pH}_{\mathrm{i}}$ in bronchiole epithelial cells}

While lower concentrations of amiloride inhibit $\mathrm{ENaC}$ with IC50 of $1 \mu \mathrm{M}$ [32], higher concentrations of amiloride (0.5-1 mM) also inhibit apical NHE in human bronchial epithelium [49]. Figure 6 shows the effects of various concentrations of luminal amiloride $(1,10$, and $100 \mu \mathrm{M}$ ) on basal $\mathrm{pH}_{\mathrm{i}}$ (Fig. 6). To examine the relative contribution of ENaC and apical NHE in $\mathrm{H}^{+} / \mathrm{HCO}_{3}{ }^{-}$ transport in a physiological condition, we examined concentration-dependent effects of luminal amiloride rather than a more specific inhibitor of NHE such as ethylisopropyl amiloride (EIPA).

In the absence of $\mathrm{HCO}_{3}{ }^{-}-\mathrm{CO}_{2}$, luminal application of amiloride caused concentration-dependent decline of $\mathrm{pH}_{\mathrm{i}}$ (Fig. 6a, c, e, g).

In the presence of $\mathrm{HCO}_{3}{ }^{-}-\mathrm{CO}_{2}$, luminal application of $1 \mu \mathrm{M}$ amiloride caused an increase in $\mathrm{pH}_{\mathrm{i}}$ by $0.03 \pm 0.01$ $(n=8$, Fig. $6 \mathrm{~b}$ and g). Luminal $100 \mu \mathrm{M}$ amiloride caused a transient increase followed by a continuous decline in $\mathrm{pH}_{\mathrm{i}}$ by $0.06 \pm 0.01(n=8)$ in $5 \mathrm{~min}$ (Fig. $6 \mathrm{f}$ and g). Luminal $10 \mu \mathrm{M}$ amiloride (Fig. $5 \mathrm{~d}$ and g) caused an intermediate pattern of $\mathrm{pH}_{\mathrm{i}}$ changes of those by $1 \mu \mathrm{M}$ and $100 \mu \mathrm{M}$ amiloride.

Thus, the effects of lower concentration of apical amiloride on basal $\mathrm{pH}_{\mathrm{i}}$ were dependent on the presence of $\mathrm{HCO}_{3}{ }^{-}-\mathrm{CO}_{2}$, which suggests that $\mathrm{ENaC}$ is involved in the regulation of $\mathrm{HCO}_{3}{ }^{-}$transport. The data also indicate that apical NHE is involved in the regulation of basal $\mathrm{pH}_{\mathrm{i}}$.

\section{Messenger RNA expression of ion transporters and channels in bronchiole epithelial cells}

Expression of Cftr, ENaC subunits, and Slc4, Slc9, and Slc26 families of transporters in isolated bronchioles and tracheal mucosa was examined by RT-PCR (Fig. 7). Amplified fragments from Cftr, $\alpha, \beta, \gamma$ subunits of $\mathrm{ENaC}$, Slc4a2 (Ae2), Slc4a3 (Ae3), Slc4a4 (NBCe1), Slc4a5 

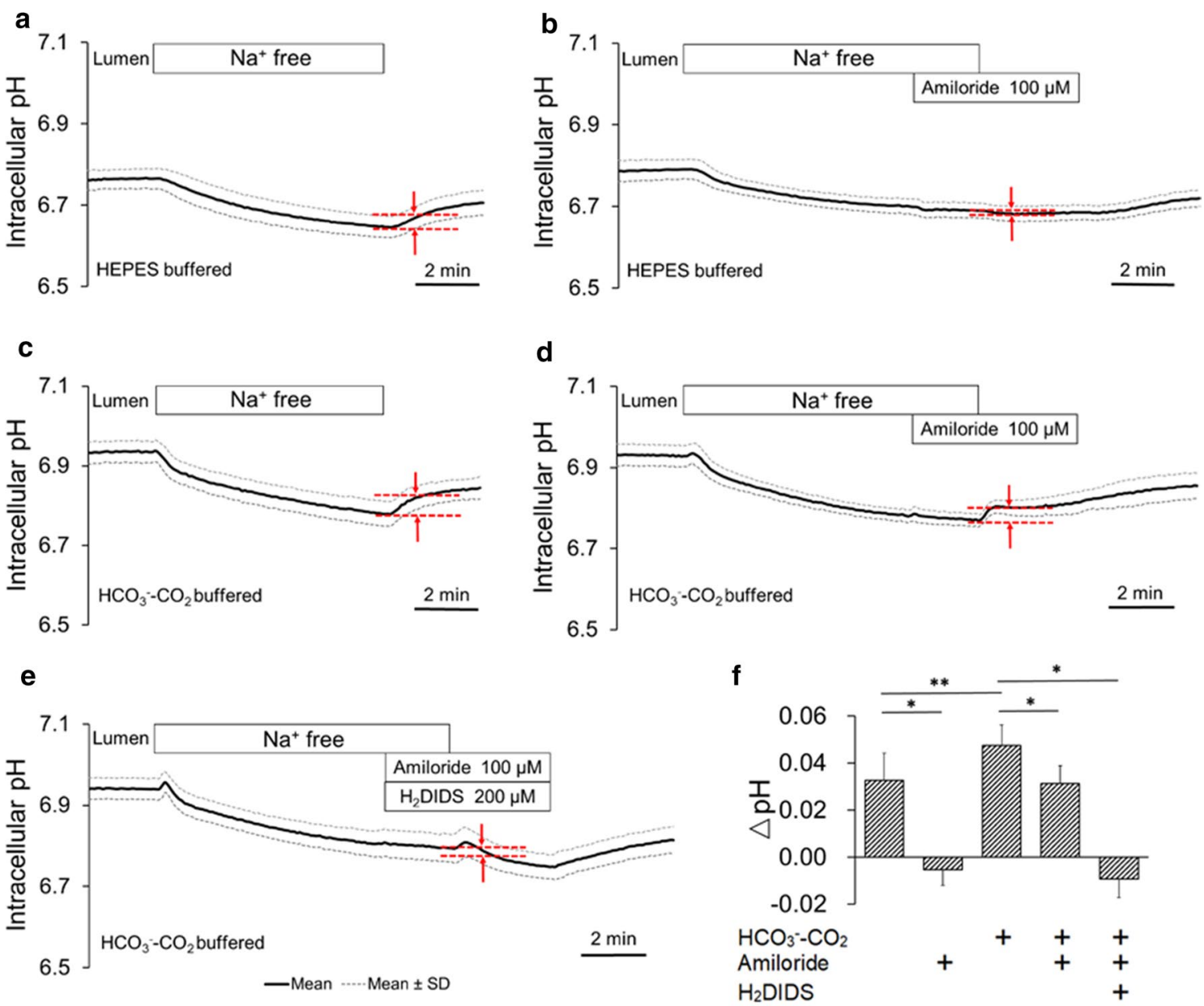

Fig. $5 \mathrm{Na}^{+}$-dependent $\mathrm{H}^{+}$extrusion across the apical membrane of bronchiole epithelial cells. a-e Isolated bronchioles were first bilaterally perfused with the standard Hepes-buffered $\mathrm{HCO}_{3}{ }^{-}-\mathrm{CO}_{2}$-free solution $(\mathbf{a}, \mathbf{b})$ or the standard $\mathrm{HCO}_{3}{ }^{-}$-buffered solution (c-e). Luminal $\mathrm{Na}^{+}$was removed by replacement with NMDG and restored to the lumen in the absence $(\mathbf{a}, \mathbf{c})$ or presence of luminal amiloride $(100 \mu \mathrm{M})(\mathbf{b}, \mathbf{d})$ or combination of luminal amiloride $(100 \mu \mathrm{M})$ and $\mathrm{H}_{2} \mathrm{DIDS}(200 \mu \mathrm{M})(\mathbf{e})$. Time course changes of $\mathrm{pH}_{\mathrm{i}}$ are shown as means \pm SD of 8 experiments. $\mathbf{f}$ The activity of luminal $\mathrm{Na}^{+}$-dependent $\mathrm{H}^{+}$extrusion is shown as the initial increase/decrease of $\mathrm{pH}_{\mathrm{i}}(\Delta \mathrm{pH}$ for $1 \mathrm{~min})$ upon restoration of luminal $\mathrm{Na}^{+}$. ${ }^{*} p<0.01,{ }^{* *} p<0.05$

(NBCe2), Slc4a7 (NBCn1), Slc4a8 (NDCBE), Slc4a10 (NBCn2), Slc9a1 (Nhe1), Slc9a2 (Nhe2), Slc9a4 (Nhe4), Slc9a5 (Nhe5), Slc26a4 (Pendrin), Slc26a6 (Pat1), and Slc26a9 were detected in isolated bronchioles and tracheal mucosa. Fragments from Slc9a3 (Nhe3) and Slc26a3 (Dra) were not detected in isolated bronchioles and tracheal mucosa.

\section{Basal $\mathrm{pH}_{\mathrm{i}}$ and apical $\mathrm{HCO}_{3}{ }^{-}$efflux in bronchiole epithelial cells from CF mice}

Basal $\mathrm{pH}_{\mathrm{i}}$ in the presence of $\mathrm{HCO}_{3}{ }^{-}-\mathrm{CO}_{2}$ in isolated bronchioles from $\Delta \mathrm{F} / \Delta \mathrm{F}$ mice $(6.97 \pm 0.02, n=6)$ was slightly but significantly $(p<0.05)$ higher compared to bronchioles from wild-type mice $(6.94 \pm 0.02, n=8$, blue line) (Fig. $8 \mathrm{a}$ and d). Initial increase of $\mathrm{pH}_{\mathrm{i}}(\Delta \mathrm{pH})$ by removal of luminal $\mathrm{HCO}_{3}{ }^{-}-\mathrm{CO}_{2}$ was also significantly $(p<0.01)$ greater in $\Delta \mathrm{F} / \Delta \mathrm{F}$ bronchioles compared to wild-type bronchioles (Fig. $8 \mathrm{a}$ and e). The data suggest that basal $\mathrm{HCO}_{3}{ }^{-}$secretion is impaired in $\mathrm{CF}$ bronchioles. The rate of $\mathrm{pH}_{\mathrm{i}}$ decline at midpoint $\mathrm{pH}_{\mathrm{i}}$ of 6.95 was significantly $(p<0.05)$ slower in CF bronchioles compared to wild-type bronchioles (Fig. 8a and g).

Stimulation with luminal forskolin $(5 \mu \mathrm{M})$ transiently accelerated $\mathrm{pH}_{\mathrm{i}}$ decline (apical $\mathrm{HCO}_{3}{ }^{-}$efflux) in $\Delta \mathrm{F} /$ $\Delta \mathrm{F}$ bronchioles (Fig. $8 \mathrm{~b}$ and $\mathrm{f}$ ) and the acceleration was comparable to wild-type bronchioles (blue line). Forskolin failed to accelerate the late phase of $\mathrm{pH}_{\mathrm{i}}$ decline (at midpoint $\mathrm{pH}_{\mathrm{i}}$ of 6.95) in $\Delta \mathrm{F} / \Delta \mathrm{F}$ bronchioles (Fig. $8 \mathrm{~b}$ and g). The data suggest that cAMP stimulation transiently activated $\mathrm{HCO}_{3}^{-}$secretion in $\mathrm{CF}$ bronchioles probably 

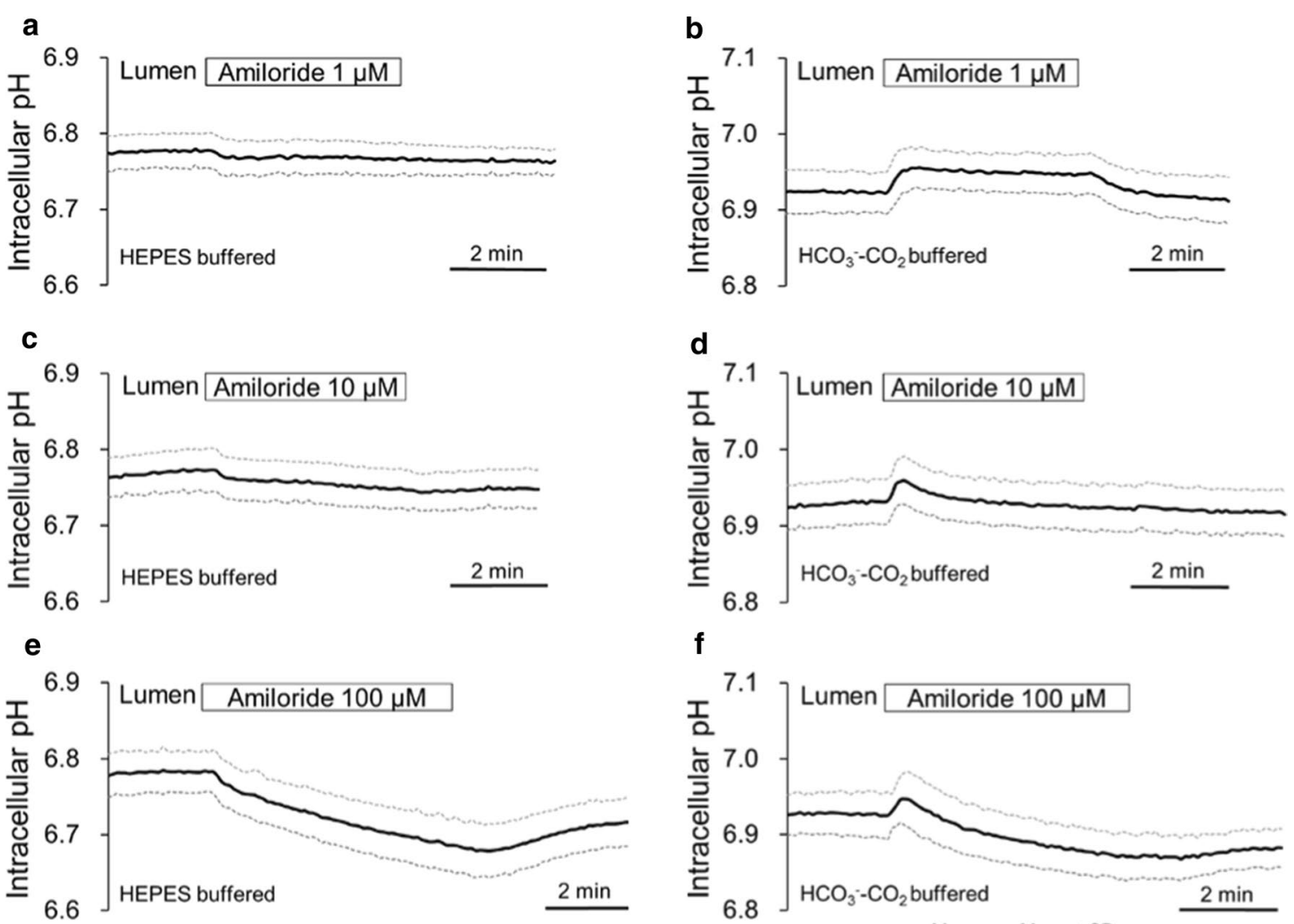

f

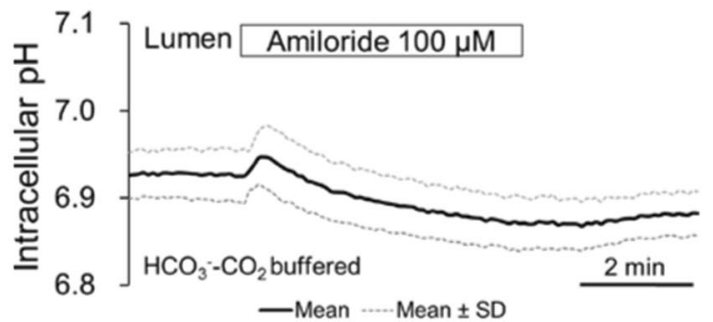

g

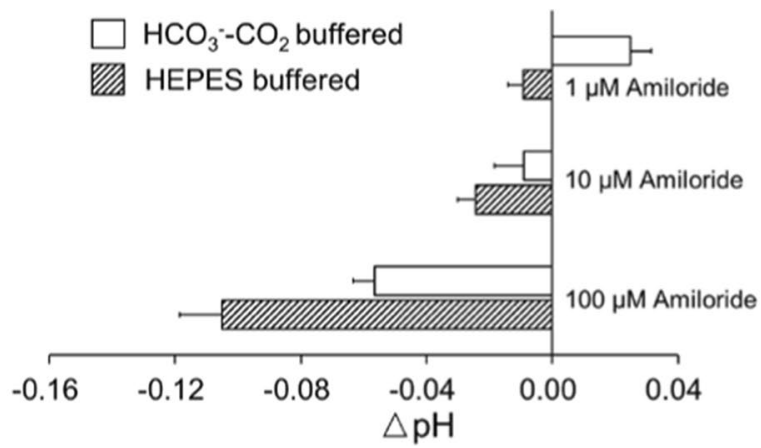

Fig. 6 Effects of luminal amiloride on $\mathrm{pH}_{\mathrm{i}}$ in bronchiole epithelial cells. a-f $\mathbf{f}$ solated bronchioles were first bilaterally perfused with the standard Hepes-buffered $\mathrm{HCO}_{3}{ }^{-}-\mathrm{CO}_{2}$-free solution $(\mathbf{a}, \mathbf{c}, \mathbf{e})$ or the standard $\mathrm{HCO}_{3}{ }^{-}$-buffered solution $(\mathbf{b}, \mathbf{d}, \mathbf{f})$. Amiloride was applied to the lumen as indicated at concentrations of $1 \mu \mathrm{M}(\mathbf{a}, \mathbf{b}), 10 \mu \mathrm{M}(\mathbf{c}, \mathbf{d})$ or $100 \mu \mathrm{M}(\mathbf{e}, \mathbf{f})$. Time course changes of $\mathrm{pH}_{\mathrm{i}}$ are shown as means $\pm \mathrm{SD}$ of 8 experiments. $\mathbf{g}$ Increase or decrease of $\mathrm{pH}_{\mathrm{i}}(\mathrm{\Delta} \mathrm{pH}$ for $5 \mathrm{~min})$ by luminal application of amiloride at various concentrations

via activation of a $\mathrm{HCO}_{3}^{-}$-permeable anion channel or a $\mathrm{HCO}_{3}{ }^{-}$transporter, but failed to induce sustained increase of $\mathrm{HCO}_{3}^{-}$secretion.

Luminal application of $\mathrm{ACh}$ induced a transient increase of transepithelial ion current in mice and pig tracheal epithelium [16, 21]. Application of ACh $(10 \mu \mathrm{M})$ to the lumen transiently accelerated $\mathrm{pH}_{\mathrm{i}}$ decline (apical $\mathrm{HCO}_{3}{ }^{-}$efflux) in wild-type bronchioles (blue line in
Fig. 8c) and the acceleration was greater than forskolin (Fig. 8f, $p<0.01$ ). The ACh-induced transient acceleration of $\mathrm{pH}_{\mathrm{i}}$ decline was reduced by $45 \%(p<0.01)$ in $\Delta \mathrm{F} / \Delta \mathrm{F}$ bronchioles (Fig. 8c and f). Luminal ACh did not affect the late phase of $\mathrm{pH}_{\mathrm{i}}$ decline in both wild-type and $\Delta \mathrm{F} /$ $\Delta \mathrm{F}$ bronchioles (Fig. $8 \mathrm{c}$ and $\mathrm{g}$ ). The data indicate that ACh stimulation transiently activated $\mathrm{HCO}_{3}{ }^{-}$secretion in wild-type bronchioles and that the ACh-induced 


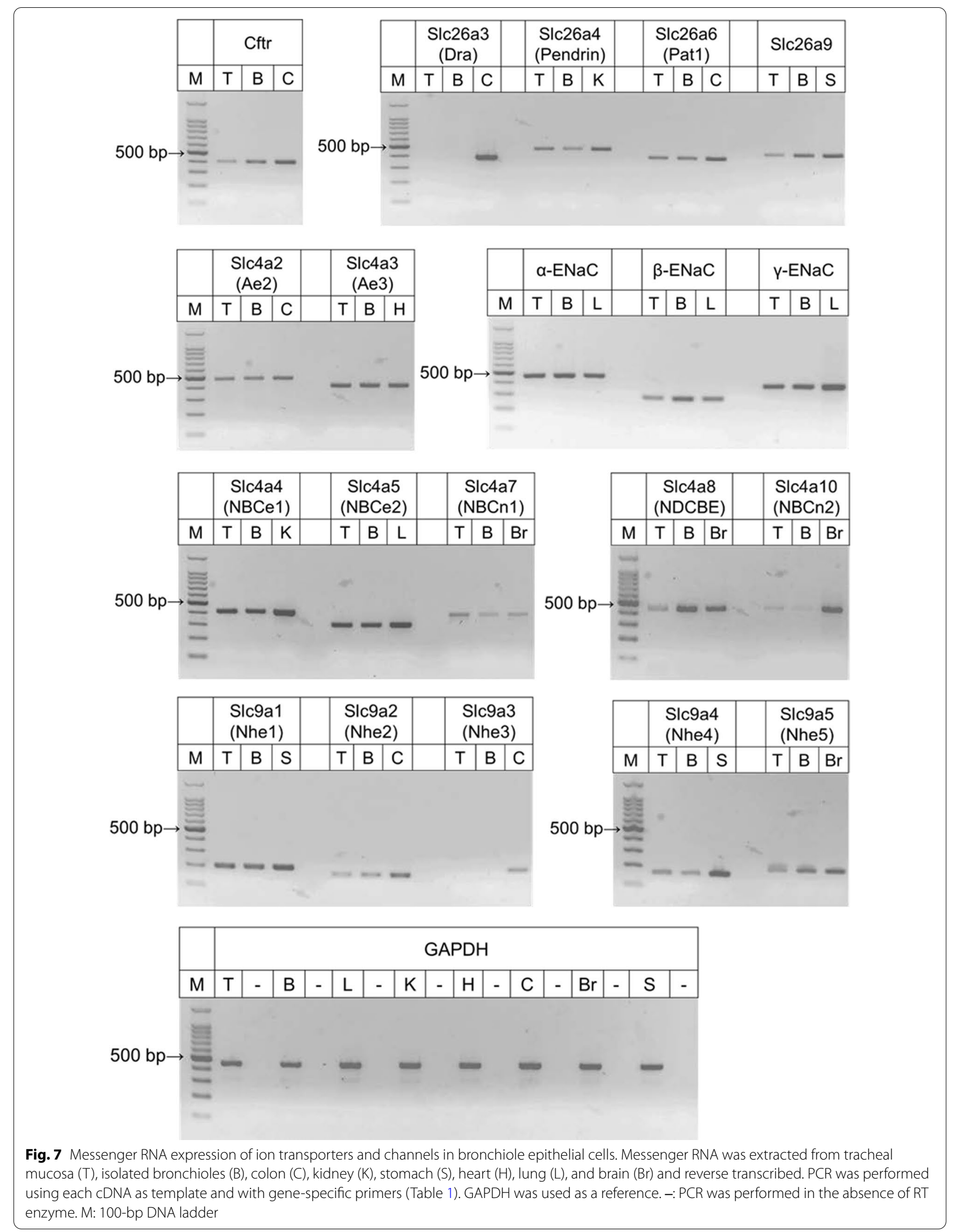



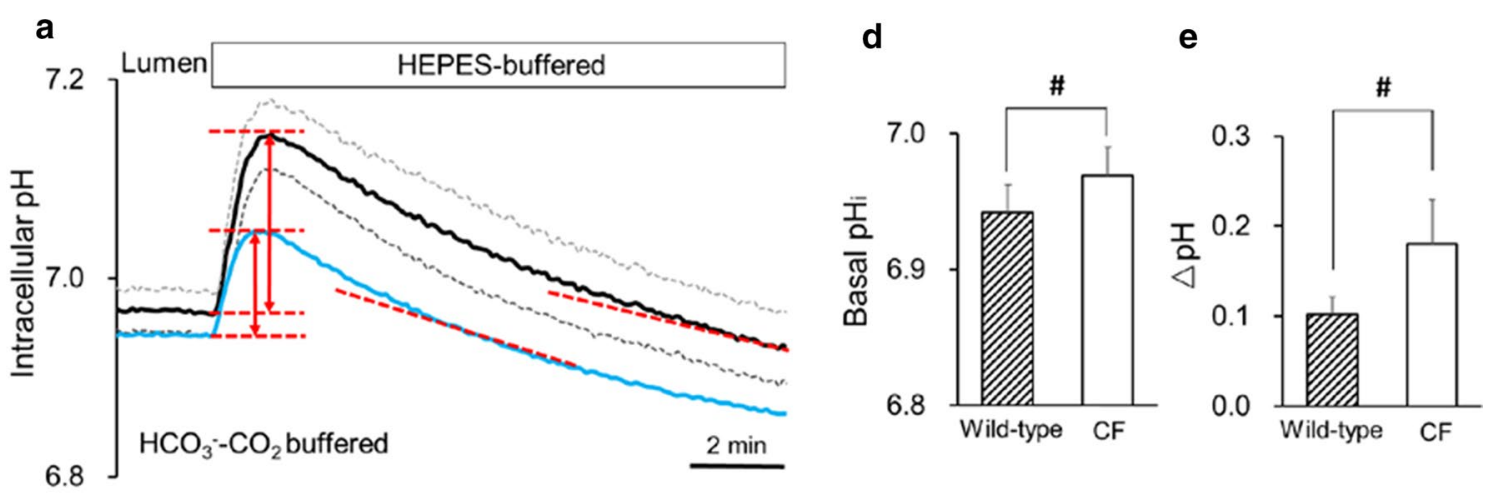

b
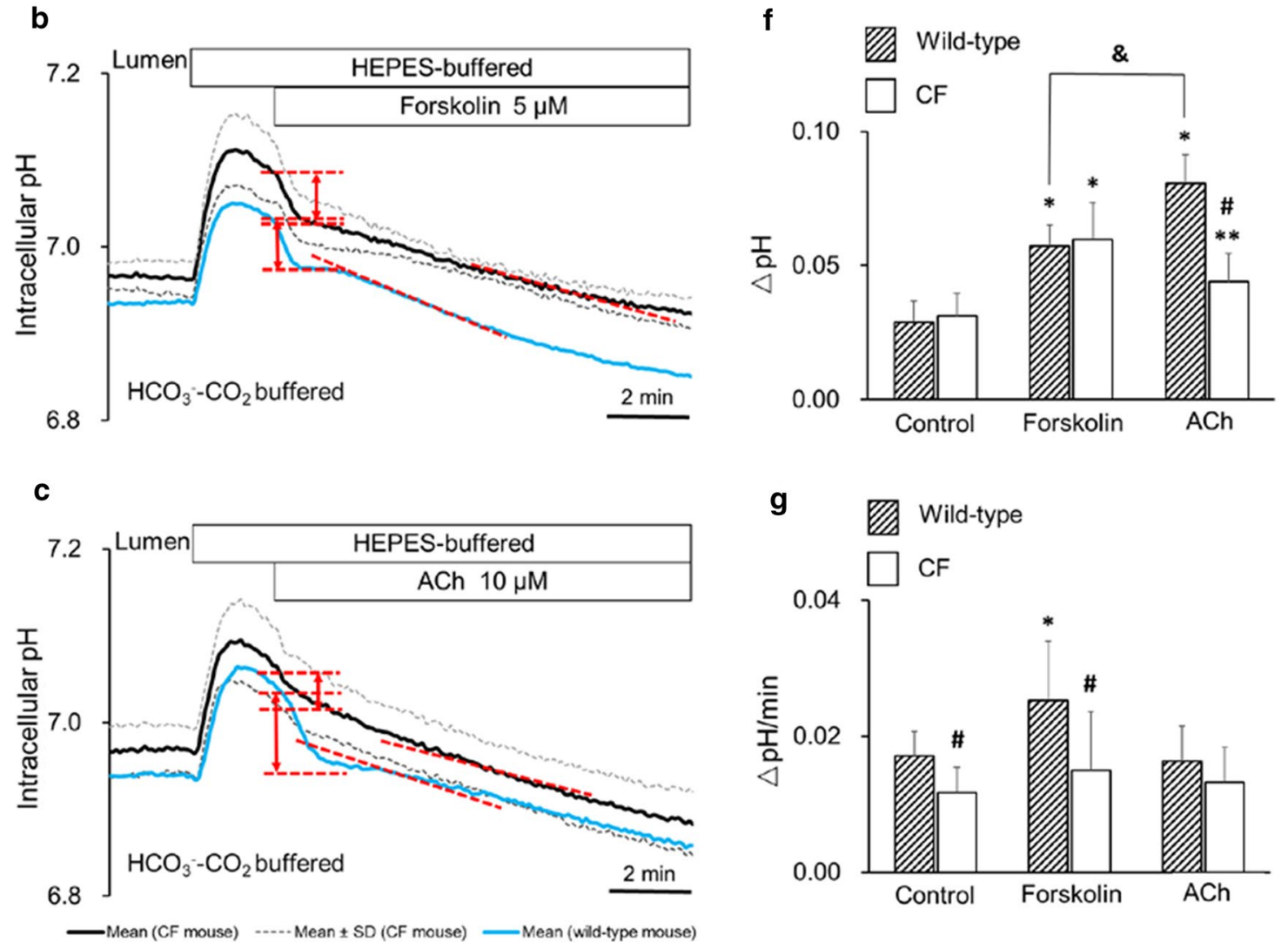

Fig. 8 Apical $\mathrm{HCO}_{3}{ }^{-}$efflux in bronchiole epithelial cells from $\mathrm{CF}$ mice. a-c Isolated bronchioles from $\triangle \mathrm{F} / \Delta \mathrm{F}$ mice were first bilaterally perfused with the standard $\mathrm{HCO}_{3}{ }^{-}$-buffered solution and the luminal perfusate was switched to the standard Hepes-buffered $\mathrm{HCO}_{3}{ }^{-}-\mathrm{CO}_{2}$-free solution After $\mathrm{HCO}_{3}{ }^{-}-\mathrm{CO}_{2}$ was removed from the luminal perfusate, forskolin $(5 \mu \mathrm{M}, \mathbf{b})$ or ACh $(10 \mu \mathrm{M}, \mathbf{c})$ was applied to the lumen. Means \pm SD of 5-6 experiments, respectively. Blue lines indicate mean changes of $\mathrm{pH}_{\mathrm{i}}$ in wild-type bronchioles as references. $\mathbf{d}$ Basal $\mathrm{pH}_{\mathrm{i}}$ in the presence of $\mathrm{HCO}_{3}{ }^{-}-\mathrm{CO}_{2}$ in wild-type $(n=8)$ and $\Delta \mathrm{F} / \Delta \mathrm{F}(n=6)$ bronchioles. ${ }^{\#} p<0.05$. e Transient increase of $\mathrm{pH}_{\mathrm{i}}(\Delta \mathrm{pH})$ by removal of luminal $\mathrm{HCO}_{3}{ }^{-}-\mathrm{CO}_{2}$ in wild-type and $\Delta \mathrm{F} / \Delta \mathrm{F}$ bronchioles. ${ }^{\#} p<0.01$. f Early-phase $\mathrm{pH}_{\mathrm{i}}$ decline $(\Delta \mathrm{pH}$ for $1 \mathrm{~min})$ just after stimulation with forskolin or acetylcholine. ${ }^{*} p<0.01 \mathrm{compared}$ to wild-type. ${ }^{*} p<0.01,{ }^{* *} p<0.05$ compared with control (without stimulation). ${ }^{\circledR} p<0.01$. $\mathbf{g}$ Late-phase $\mathrm{pH}_{\mathrm{i}}$ decline $(\Delta \mathrm{pH} / \mathrm{min}$ at midpoint $\mathrm{pH}$ i of 6.95) under stimulation with forskolin or ACh (red dashed lines in $\mathbf{a}-\mathbf{c}$ ). ${ }^{*} p<0.05$ compared with control (without stimulation). ${ }^{*} p<0.05$ compared to wild-type

enhancement of $\mathrm{HCO}_{3}{ }^{-}$secretion was substantially reduced in $\mathrm{CF}$ bronchioles. This suggests that CFTR partly mediates $\mathrm{ACh}$-induced $\mathrm{HCO}_{3}^{-}$secretion in addition to $\mathrm{CaCC}$ in mice bronchiole epithelial cells.

\section{Discussion}

In the present study, $\mathrm{HCO}_{3}{ }^{-}$transport in surface epithelial cells of native bronchioles was studied by measuring $\mathrm{pH}_{\mathrm{i}}$ in luminally microperfused freshly dissected mice 
bronchioles. $\mathrm{HCO}_{3}{ }^{-}$transport in bronchioles from $\mathrm{CF}$ mice was also studied. Although some connective tissue was attached to the outside of bronchioles (Fig. 1), surface epithelial cells were successfully loaded with BCECF from the lumen and $\mathrm{pH}_{\mathrm{i}}$ was measured as long as $30 \mathrm{~min}$. The present study focused on $\mathrm{HCO}_{3}^{-} / \mathrm{H}^{+}$transport across the apical membrane, since rapid exchange of luminal solutions was achieved in our preparation [22].

\section{Intracellular pH in surface epithelial cells of mice bronchioles}

Human and rodent bronchioles are lined with columnar to cuboidal epithelium which is composed of ciliated and nonciliated (Clara) cells [35]. In the present study, basal $\mathrm{pH}_{\mathrm{i}}$ of surface epithelial cells in isolated mice bronchioles was $\sim 6.94$ in bilateral (bath and lumen) presence of $25 \mathrm{mM} \mathrm{HCO}_{3}{ }^{-}$and $5 \% \mathrm{CO}_{2}$. The value is similar to the basal $\mathrm{pH}_{\mathrm{i}}$ of cultured human nasal epithelial cells ( 6.94) in the same experimental condition [37]. The relatively low basal $\mathrm{pH}_{\mathrm{i}}$ likely resulted from higher $\mathrm{pCO}_{2}$ in the lumen compared to the physiological in vivo situation where the luminal side of the epithelial layer is exposed to air.

\section{Ion transporters and channels localized in the apical membrane of bronchiole epithelial cells}

In the present study, functional studies suggested that CFTR and $\mathrm{H}_{2}$ DIDS-sensitive $\mathrm{HCO}_{3}{ }^{-}$transporter and/or $\mathrm{HCO}_{3}{ }^{-}$-permeable anion channel mediate cAMP-stimulated $\mathrm{HCO}_{3}{ }^{-}$secretion and $\mathrm{ENaC}, \mathrm{H}_{2}$ DIDS-sensitive $\mathrm{Cl}^{-}-\mathrm{HCO}_{3}^{-}$exchangers, NHE, and NBC are involved in $\mathrm{HCO}_{3}{ }^{-} / \mathrm{H}^{+}$transport across the apical membrane of surface epithelial cells of mice bronchioles (Fig. 9). This is supported by mRNA expression of $\mathrm{Cftr}, \mathrm{ENaC}$ subunits, and Slc4, Slc9, and Slc26 families of transporters (Fig. 7).

The activity of $\mathrm{H}_{2}$ DIDS-sensitive $\mathrm{Cl}^{-}-\mathrm{HCO}_{3}{ }^{-}$ exchanger was detected in the apical membrane (Fig. 4) and probably mediated part of cAMP-stimulated $\mathrm{HCO}_{3}{ }^{-}$ secretion (Fig. 3c). The candidate molecules are Slc4a2 (Ae2), Slc4a3 (Ae3), Slc26a4 (Pendrin), Slc26a6, and Slc26a9 of which mRNA expression was detected in isolated bronchioles (Fig. 7). In human bronchial epithelia, SLC26A4 (Pendrin) colocalized with CFTR in the apical membrane of ciliated surface cells and mediated most of $\mathrm{HCO}_{3}{ }^{-}$secretion when pretreated with IL-4 [24]. SLC26A9 is prominently expressed in brain and on apical membrane of airway epithelial cells and gastric mucosa $[3,31]$. A missense variant of SLC26A9 found in a patient of diffuse bronchiectasis failed to activate CFTR in a heterologous expression system [7]. While Slc26a4 (Pendrin) is $\mathrm{H}_{2}$ DIDS-insensitive, Slc26a9 is sensitive to $\mathrm{H}_{2}$ DIDS. Thus, Slc26a9 is likely the major apical $\mathrm{Cl}^{-}-\mathrm{HCO}_{3}{ }^{-}$ exchanger in mice bronchioles.

Apical $\mathrm{H}^{+}$secretion via $\mathrm{H}^{+} / \mathrm{K}^{+}$ATPase and vacuolar $\mathrm{H}^{+}$-ATPase was reported in airways [52]. Our present study identified the activities of NHE and NBC in the apical membrane of mice bronchioles (Figs. 5, 6) which may contribute to the regulation of intracellular and ASL $\mathrm{pH}$.

NHE activity was detected in the apical membrane and mediated $\mathrm{H}^{+}$secretion in tracheal epithelial cells from sheep [1]. The candidate molecules of apical NHE in mice bronchioles are Slc9a1 (Nhe1), Slc9a2 (Nhe2), Slc9a4 (Nhe4), and Slc9a5 (Nhe5) of which mRNA expression was detected (Fig. 7). NHE2 is known to be expressed in the lung, predominantly localized to the apical membrane of epithelial cells [19], and relatively sensitive to

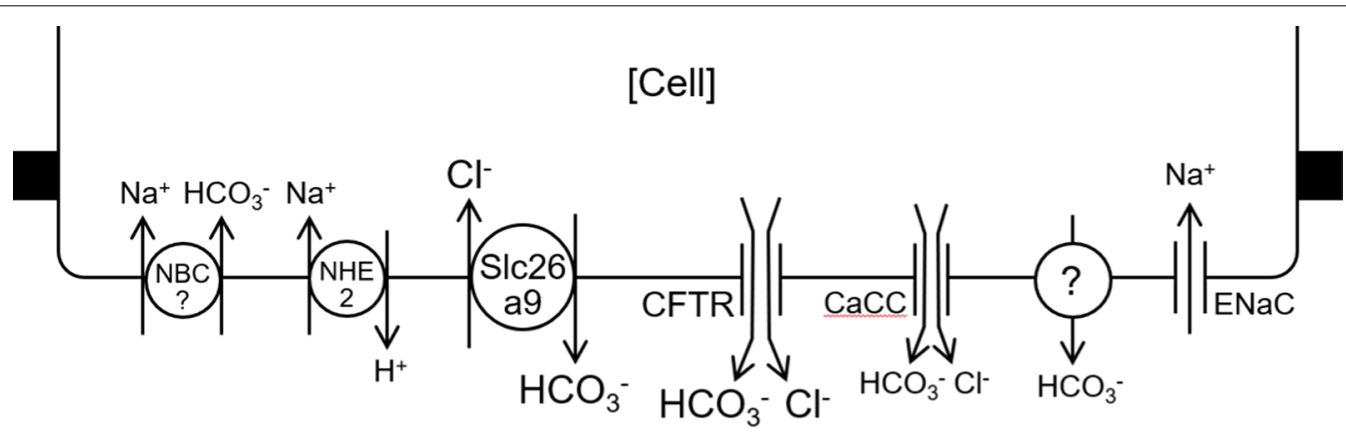

[ASL]

Fig. 9 A hypothetical model for $\mathrm{H}^{+} / \mathrm{HCO}_{3}{ }^{-}$transport across the apical membrane of airway surface epithelial cells in mice bronchiole. $\mathrm{HCO}_{3}{ }^{-}$ secretion across the apical membrane is largely mediated by CFTR and Slc26a9 $\mathrm{Cl}^{-}-\mathrm{HCO}_{3}{ }^{-}$exchanger. $\mathrm{CaCC}$ is also involved in $\mathrm{HCO}_{3}{ }^{-}$secretion. An unknown $\mathrm{HCO}_{3}{ }^{-}$-permeable anion channel or $\mathrm{HCO}_{3}{ }^{-}$transporter is upregulated in $\mathrm{CF}$ bronchioles. $\mathrm{ENaC}$ is involved in the regulation of $\mathrm{HCO}_{3}{ }^{-}$ transport but the mechanisms are not clear. NHE2 and NBC contribute to the regulation of intracellular and ASL pH 
amiloride [51]. Thus, NHE2 is likely the major apical $\mathrm{Na}^{+}-\mathrm{H}^{+}$exchanger in mice bronchioles.

While SlC4A4 (NBCe1) and SLC4A5 (NBCe2) were identified in the basolateral membrane of Calu-3 cells [27], NBC isoforms have not been identified in the apical membrane of airway epithelium. Messenger RNA of all NBC isoforms: Slc4a4 (NBCe1), Slc4a5 (NBCe2), Slc4a7 (NBCn1), Slc4a8 (NDCBE), and Slc4a10 (NBCn2) was detected in isolated mice bronchioles (Fig. 7). Our present study cannot identify the membrane localization of the NBC isoforms.

\section{Mechanisms and regulation of $\mathrm{HCO}_{3}{ }^{-}$secretion in bronchiole epithelial cells}

Surface airway epithelial cells as well as serous cells of the submucosal glands secrete $\mathrm{Cl}^{-}$and $\mathrm{HCO}_{3}{ }^{-}$in response to agents increasing intracellular cAMP (VIP, noradrenaline, etc.) and/or $\mathrm{Ca}^{2+}$ (ACh, histamine, etc.) [41]. It is generally accepted that cAMP-mediated secretion involves CFTR and $\mathrm{Ca}^{2+}$-mediated secretion involves CaCC encoded by TMEM16A/ANO1 [15]. Cyclic AMP- and $\mathrm{Ca}^{2+}$-mediated agonists independently and additively increased $\mathrm{HCO}_{3}{ }^{-}$secretion in human bronchioles [45]. However, it has been noted that muscarinic responses of fluid secretion are reduced in submucosal glands from patients with cystic fibrosis [42] and a recent study demonstrated a crosstalk of CFTR and TMEM16A in CFBE cells [29].

We assume that continuous decline of $\mathrm{pH}_{\mathrm{i}}$ following alkaline load (Figs. 2, 3, 8) demonstrates time course of $\mathrm{HCO}_{3}{ }^{-}$secretion into the lumen which is perfused with the $\mathrm{HCO}_{3}{ }^{-}$-free solution. Forskolin biphasically stimulated $\mathrm{HCO}_{3}{ }^{-}$secretion: transiently accelerated $\mathrm{HCO}_{3}{ }^{-}$ secretion just after application and increased the rate of steady-state $\mathrm{HCO}_{3}{ }^{-}$secretion (Fig. 3a). ACh transiently accelerated $\mathrm{HCO}_{3}{ }^{-}$secretion, but did not increase the steady-state $\mathrm{HCO}_{3}{ }^{-}$secretion (Fig. 8c). The data indicate that both cAMP-mediated and $\mathrm{Ca}^{2+}$-mediated pathways are involved in $\mathrm{HCO}_{3}{ }^{-}$secretion in mice bronchiole epithelial cells.

Luminal CFTR inh $^{-172}$ and $\mathrm{H}_{2}$ DIDS substantially inhibited both transient and steady-state phases of forskolinstimulated $\mathrm{HCO}_{3}{ }^{-}$secretion (Fig. 3). CFTR was localized not only in serous cells of submucosal glands [17, 23], but also in the apical membrane of surface epithelium of proximal to distal airways in human [26]. GlyH101sensitive $\mathrm{HCO}_{3}{ }^{-}$transport was detected in human bronchioles [45]. Our present data suggest that both CFTR and $\mathrm{H}_{2}$ DIDS-sensitive $\mathrm{HCO}_{3}{ }^{-}$transporter (likely SLC26A9 $\mathrm{Cl}^{-}-\mathrm{HCO}_{3}{ }^{-}$exchanger shown in Fig. 4) and/or $\mathrm{HCO}_{3}{ }^{-}$-permeable anion channel are involved in apical $\mathrm{HCO}_{3}{ }^{-}$secretion (Fig. 9).
A relatively low concentration of amiloride in the lumen inhibited transient phase of forskolin-stimulated $\mathrm{HCO}_{3}{ }^{-}$secretion (Fig. 3e). The data suggest that $\mathrm{ENaC}$ is involved in the regulation of $\mathrm{HCO}_{3}{ }^{-}$transport, which is consistent with amiloride $(1 \mu \mathrm{M})$-induced $\mathrm{pH}_{\mathrm{i}}$ increase in the presence of $\mathrm{HCO}_{3}{ }^{-}-\mathrm{CO}_{2}$ (Fig. 6). The cellular mechanisms for the involvement of $\mathrm{ENaC}$ in $\mathrm{HCO}_{3}{ }^{-}$secretion are not clear.

\section{$\mathrm{HCO}_{3}{ }^{-}$secretion in $\mathrm{CF}$ bronchiole epithelial cells}

ASL pH was more acidic in trachea of CF pigs under basal and methacholine-stimulated conditions [38]. Lower $\mathrm{pH}$ of ASL was also observed in nasal epithelium of CF patients [34, 52], while the other study did not find differences in ASL pH of bronchus between CF patients and control [43]. Combination of forskolin and 3-isobutyl-1-methylxanthine alkalinized ASL of cultured bronchial epithelium of normal subjects but acidified CF ASL [12].

In the present study, $\mathrm{HCO}_{3}{ }^{-}$secretion was studied in bronchioles isolated from a CF mouse model in which the F508del mutation (most frequent pathogenic variant of CFTR) was introduced ( $\Delta \mathrm{F}$ mouse) (Fig. 8). Although $\mathrm{CF}$ mice do not display severe lung disease as observed in humans, an impaired ability to stretch/expand the peripheral lung compartment and increased distances between gas exchange surfaces which are early pulmonary phenotype of human CF were found in young (8-16 weeks old) $\Delta \mathrm{F} / \Delta \mathrm{F}$ mice [14]. Our present study demonstrated higher level of basal $\mathrm{pH}_{\mathrm{i}}$ in the presence of $\mathrm{HCO}_{3}{ }^{-}-\mathrm{CO}_{2}$ and larger increase of $\mathrm{pH}_{\mathrm{i}}$ by removal of luminal $\mathrm{HCO}_{3}{ }^{-}-\mathrm{CO}_{2}$ in $\mathrm{CF}$ bronchioles (Fig. 8), which indicate that basal $\mathrm{HCO}_{3}{ }^{-}$secretion is reduced in $\mathrm{CF}$ distal airways.

The effects of forskolin and $\mathrm{ACh}$ on $\mathrm{HCO}_{3}{ }^{-}$secretion in CF bronchioles (Fig. 8) were unexpected. While forskolin stimulation transiently accelerated $\mathrm{HCO}_{3}{ }^{-}$secretion in $\mathrm{CF}$ bronchioles (comparable to wild-type bronchioles, Fig. 8b), ACh-induced acceleration of $\mathrm{HCO}_{3}{ }^{-}$secretion was substantially reduced in CF bronchioles (Fig. 8c). The data are consistent with the presence of a crosstalk of cAMP- and $\mathrm{Ca}^{2+}$-mediated pathways of $\mathrm{HCO}_{3}{ }^{-}$ secretion. The data also suggest that a cAMP-activated $\mathrm{HCO}_{3}{ }^{-}$-permeable anion channel or $\mathrm{HCO}_{3}{ }^{-}$transporter was upregulated in CF bronchioles.

The present study has some limitations. (1) The intracellular buffering capacity is not measured and the rate of $\mathrm{H}^{+} / \mathrm{HCO}_{3}{ }^{-}$flux is not inferred from changes in $\mathrm{pH}_{\mathrm{i}}$. (2) Information of membrane potential is not available and the electrochemical potential gradient for $\mathrm{HCO}_{3}{ }^{-}$ across the apical membrane is not accurately predicted. (3) RT-PCR of isolated bronchioles does not identify 
the cell types (ciliated or nonciliated) and the membrane (apical or basolateral) in which transporters/ channels are located.

In summary, we have characterized $\mathrm{HCO}_{3}{ }^{-} / \mathrm{H}^{+}$transport across the apical membrane of surface epithelial cells of native mice bronchioles. We have demonstrated that cAMP-mediated and $\mathrm{Ca}^{2+}$-mediated pathways are involved in $\mathrm{HCO}_{3}{ }^{-}$secretion and that apical $\mathrm{HCO}_{3}{ }^{-}$ secretion is largely mediated by CFTR and $\mathrm{Cl}^{-}-\mathrm{HCO}_{3}^{-}$ exchange. The impairment of $\mathrm{HCO}_{3}{ }^{-}$secretion in $\mathrm{CF}$ bronchioles may be related to the pathogenesis of early lung disease in CF.

\section{Authors' contributions}

All authors contributed to the study conception and design. Material preparation, data collection and analysis were performed by LL, AY, MY, IT, NN, MN, $Y K, T F, M H, E N, T T$, and $H I$. The first draft of the manuscript was written by LL and $\mathrm{HI}$ and all authors commented on previous versions of the manuscript. All authors read and approved the final manuscript.

\section{Funding}

Libin Liu received Japanese Government (MEXT) Scholarship and China Scholarship Council (CSC) Scholarship. This work was supported by grants from the Japan Society for the Promotion of Science and the Japanese study group for pediatric rare and intractable hepato-biliary-pancreatic diseases provided by the Ministry of Health, Labour, and Welfare of Japan.

\section{Availability of data and materials}

All data generated or analyzed during this study are included in the manuscript.

\section{Code availability}

Not applicable.

\section{Declarations}

\section{Ethics approval and consent to participate}

The study was approved by the Ethical Committee on Animal Use for Experiment (approval No. M210457-003) and the Recombinant DNA Experiment Safety Committee (approval No. 20-93) of Nagoya University.

\section{Consent for publication}

Not applicable.

\section{Competing interests}

The authors have no conflicts of interest to declare that are relevant to the content of this article.

\section{Author details}

${ }^{1}$ Department of Human Nutrition, Nagoya University Graduate School of Medicine, Nagoya, Japan. ${ }^{2}$ Department of Respiratory Medicine, Tohoku University Graduate School of Medicine, Sendai, Japan. ${ }^{3}$ Research Center of Health, Physical Fitness, and Sports, Nagoya University, Furo-cho E5-2 (130), Chikusa-ku, Nagoya 464-8601, Japan.

Received: 26 December 2021 Accepted: 14 February 2022

Published online: 23 February 2022

\section{References}

1. Acevedo M, Steele LW (1993) $\mathrm{Na}^{+}-\mathrm{H}^{+}$exchanger in isolated epithelial tracheal cells from sheep. Involvement in tracheal proton secretion. Exp Physiol 78:383-394. https://doi.org/10.1113/expphysiol.1993.sp003692
2. Al-Bazzaz FJ, Tarka C, Farah M (1991) Microperfusion of sheep bronchioles. Am J Physiol 260:594-602. https://doi.org/10.1152/ajplung.1991.260.6. L594

3. Alper SL, Sharma AK (2013) The SLC26 gene family of anion transporters and channels. Mol Aspects Med 34:494-515. https://doi.org/10.1016/j. mam.2012.07.009

4. Ambort D, Johansson ME, Gustafsson JK, Ermund A, Hansson GC (2012) Perspectives on mucus properties and formation-lessons from the biochemical world. Cold Spring Harb Perspect Med 2:a014159. https:// doi.org/10.1101/cshperspect.a014159

5. Aritake H, Tamada T, Murakami K, Gamo S, Nara M, Kazama I, Ichinose M, Sugiura H (2021) Effects of indacaterol on the LPS-evoked changes in fluid secretion rate and $\mathrm{pH}$ in swine tracheal membrane. Pflugers Arch 473:883-896. https://doi.org/10.1007/s00424-021-02560-z

6. Ballard ST, Schepens SM, Falcone JC, Meininger GA, Taylor AE (1992) Regional bioelectric properties of porcine airway epithelium. J Appl Physiol 73:2021-2027. https://doi.org/10.1152/jappl.1992.73.5.2021

7. Bakouh N, Bienvenu T, Thomas A, Ehrenfeld J, Liote H, Roussel D, Duquesnoy P, Farman N, Viel M, Cherif-Zahar B, Amselem S, Taam RA, Edelman A, Planelles G, Sermet-Gaudelus I (2013) Characterization of SLC26A9 in patients with CF-like lung disease. Hum Mutat 34:1404-1414. https://doi.org/10.1002/humu.22382

8. Ballard ST, Spadafora D (2007) Fluid secretion by submucosal glands of the tracheobronchial airways. Respir Physiol Neurobiol 159:271-277. https://doi.org/10.1016/j.resp.2007.06.017

9. Blouquit S, Morel H, Hinnrasky J, Naline E, Puchelle E, Chinet T (2002) Characterization of ion and fluid transport in human bronchioles. Am J Respir Cell Mol Biol 27:503-510. https://doi.org/10.1165/rcmb.4869

10. Blouquit-Laye S, Chinet T (2007) Ion and liquid transport across the bronchiolar epithelium. Respir Physiol Neurobiol 159:278-282. https://doi.org/ 10.1016/j.resp.2007.03.007

11. Coakley RD, Boucher RC (2001) Regulation and functional significance of airway surface liquid $\mathrm{pH}$. JOP 2:294-300

12. Coakley RD, Grubb BR, Paradiso AM, Gatzy JT, Johnson LG, Kreda SM, O'Neal WK, Boucher RC (2003) Abnormal surface liquid pH regulation by cultured cystic fibrosis bronchial epithelium. Proc Natl Acad Sci USA 100:16083-16088. https://doi.org/10.1073/pnas.2634339100

13. Cooper JL, Quinton PM, Ballard ST (2013) Mucociliary transport in porcine trachea: differential effects of inhibiting chloride and bicarbonate secretion. Am J Physiol Lung Cell Mol Physiol 304:184-190. https://doi.org/10. 1152/ajplung.00143.2012

14. Darrah RJ, Mitchell AL, Campanaro CK, Barbato ES, Litman P, Sattar A, Hodges CA, Drumm ML, Jacono FJ (2016) Early pulmonary disease manifestations in cystic fibrosis mice. J Cyst Fibros 15:736-744. https://doi.org/ 10.1016/j.jcf.2016.05.002

15. Danahay H, Gosling M (2020) TMEM16A: an alternative approach to restoring airway anion secretion in cystic fibrosis? Int J Mol Sci 21:2386. https://doi.org/10.3390/ijms21072386

16. Dittrich NP, Kummer W, Clauss WG, Fronius M (2015) Luminal acetylcholine does not affect the activity of the CFTR in tracheal epithelia of pigs. Int Immunopharmacol 29:166-172. https://doi.org/10.1016/j.intimp.2015. 08.010

17. Engelhardt JF, Yankaskas JR, Ernst SA, Yang Y, Marino CR, Boucher RC, Cohn JA, Wilson JM (1992) Submucosal glands are the predominant site of CFTR expression in the human bronchus. Nat Genet 2:240-248. https://doi.org/10.1038/ng1192-240

18. Folkesson HG, Matthay MA, Frigeri A, Verkman AS (1996) Transepithelial water permeability in microperfused distal airways. Evidence for channelmediated water transport. J Clin Invest 97:664-671. https://doi.org/10. 1172/JCl118463

19. Fuster DG, Alexander RT (2014) Traditional and emerging roles for the SLC9 Na $/ \mathrm{H}^{+}$exchangers. Pflugers Arch 466:61-76. https://doi.org/10. 1007/s00424-013-1408-8

20. Garnett JP, Hickman E, Tunkamnerdthai O, Cuthbert AW, Gray MA (2013) Protein phosphatase 1 coordinates CFTR-dependent airway epithelial HCO3- secretion by reciprocal regulation of apical and basolateral membrane Cl-HCO3- exchangers. Br J Pharmacol 168:1946-1960. https://doi. org/10.1111/bph.12085

21. Hollenhorst MI, Lips KS, Wolff M, Wess J, Gerbig S, Takats Z, Kummer W, Fronius M (2012) Luminal cholinergic signalling in airway lining fluid: a novel mechanism for activating chloride secretion via $\mathrm{Ca}^{2+}$-dependent 
$\mathrm{Cl}^{-}$and $\mathrm{K}^{+}$channels. Br J Pharmacol 166:1388-1402. https://doi.org/10. 1111/j.1476-5381.2012.01883.x

22. Ishiguro H, Steward MC, Yamamoto A (2011) Microperfusion and micropuncture analysis of ductal secretion. Pancreapedia Exocrine Pancreas Knowl Base. https://doi.org/10.3998/panc.2011.16

23. Jacquot J, Puchelle E, Hinnrasky J, Fuchey C, Bettinger C, Spilmont C, Bonnet N, Dieterle A, Dreyer D, Pavirani A, Dalemans W (1993) Localization of the cystic fibrosis transmembrane conductance regulator in airway secretory glands. Eur Respir J 6:169-176

24. Kim D, Huang J, Billet A, Abu-Arish A, Goepp J, Matthes E, Tewfik MA, Frenkiel S, Hanrahan JW (2019) Pendrin mediates bicarbonate secretion and enhances cystic fibrosis transmembrane conductance regulator function in airway surface epithelia. Am J Respir Cell Mol Biol 60:705-716. https:// doi.org/10.1165/rcmb.2018-01580C

25. Kim D, Kim J, Burghardt B, Best L, Steward MC (2014) Role of anion exchangers in $\mathrm{Cl}^{-}$and $\mathrm{HCO}_{3}{ }^{-}$secretion by the human airway epithelial cell line Calu-3. Am J Physiol Cell Physiol 307:208-219. https://doi.org/10. 1152/ajpcell.00083.2014

26. Kreda SM, Mall M, Mengos A, Rochelle L, Yankaskas J, Riordan JR, Boucher RC (2005) Characterization of wild-type and deltaF508 cystic fibrosis transmembrane regulator in human respiratory epithelia. Mol Biol Cell 16:2154-2167. https://doi.org/10.1091/mbc.e04-11-1010

27. Kreindler JL, Peters KW, Frizzell RA, Bridges RJ (2006) Identification and membrane localization of electrogenic sodium bicarbonate cotransporters in Calu-3 cells. Biochim Biophys Acta 1762:704-710. https://doi.org/ 10.1016/j.bbadis.2006.06.005

28. Krouse ME, Talbott JF, Lee MM, Joo NS, Wine JJ (2004) Acid and base secretion in the Calu-3 model of human serous cells. Am J Physiol Lung Cell Mol Physiol 287:1274-1283. https://doi.org/10.1152/ajplung.00036. 2004

29. Lérias J, Pinto M, Benedetto R, Schreiber R, Amaral M, Aureli M, Kunzelmann K (2018) Compartmentalized crosstalk of CFTR and TMEM16A (ANO1) through EPAC1 and ADCY1. Cell Signal 44:10-19. https://doi.org/ 10.1016/j.cellsig.2018.01.008

30. Lee RJ, Foskett JK (2010) Mechanisms of $\mathrm{Ca}^{2+}$-stimulated fluid secretion by porcine bronchial submucosal gland serous acinar cells. Am J Physiol Lung Cell Mol Physiol 298:L210-231. https://doi.org/10.1152/ajplung. 00342.2009

31. Lohi H, Kujala M, Makela S, Lehtonen E, Kestila M, Saarialho-Kere U, Markovich D, Kere J (2002) Functional characterization of three novel tissue-specific anion exchangers SLC26A7, -A8, and -A9. J Biol Chem 277:14246-14254. https://doi.org/10.1074/jbc.M111802200

32. Mall M, Bleich M, Greger R, Schreiber R, Kunzelmann K (1998) The amiloride-inhibitable $\mathrm{Na}^{+}$conductance is reduced by the cystic fibrosis transmembrane conductance regulator in normal but not in cystic fibrosis airways. J Clin Invest 102:15-21. https://doi.org/10.1172/JC12729

33. Mall M, Boucher RC (2006) Pathogenesis of pulmonary disease in cystic fibrosis. In: Bush A, Alton EWFW, Davies JC, Griesenbach U, Jaffe A (eds) Cystic fibrosis in the 21st century. Karger, Basel, pp 116-121 https://doi. org/10.1159/000088489

34. McShane D, Davies JC, Davies MG, Bush A, Geddes DM, Alton EW (2003) Airway surface $\mathrm{pH}$ in subjects with cystic fibrosis. Eur Respir J 21:37-42. https://doi.org/10.1183/09031936.03.00027603

35. Meyerholz DK, Suarez CJ, Dintzis SM, Frevert CW (2018) Respiratory system. In: Treuting PM, Dintzis SM, Montine KS Eds. Comparative anatomy and histology, a mouse, rat, and human atlas. 2nd edn. Academic Press, Cambridge, pp 147-162. https://doi.org/10.1016/B978-0-12-802900-8. 00009-9

36. Paradiso AM (1997) ATP-activated basolateral $\mathrm{Na}+/ \mathrm{H}+$ exchange in human normal and cystic fibrosis airway epithelium. Am J Physiol 273:L148-L158. https://doi.org/10.1152/ajplung.1997.273.1.L148

37. Paradiso AM, Coakley RD, Boucher RC (2003) Polarized distribution of $\mathrm{HCO}_{3}{ }^{-}$transport in human normal and cystic fibrosis nasal epithelia. J Physiol 548:203-218. https://doi.org/10.1113/jphysiol.2002.034447

38. Pezzulo AA, Tang XX, Hoegger MJ, Abou Alaiwa MH, Ramachandran S, Moninger TO, Karp PH, Wohlford-Lenane CL, Haagsman HP, van Eijk M, Bánfi B, Horswill AR, Stoltz DA, McCray PB Jr, Welsh MJ, Zabner J (2012) Reduced airway surface $\mathrm{pH}$ impairs bacterial killing in the porcine cystic fibrosis lung. Nature 487:109-113. https://doi.org/10.1038/nature11130
39. Quinton PM (2008) Cystic fibrosis: impaired bicarbonate secretion and mucoviscidosis. Lancet 372:415-417. https://doi.org/10.1016/S01406736(08)61162-9

40. Roos A, Boron WF (1981) Intracellular pH. Physiol Rev 61:296-434. https:// doi.org/10.1152/physrev.1981.61.2.296

41. Saint-Criq V, Gray MA (2017) Role of CFTR in epithelial physiology. Cell Mol Life Sci 74:93-115. https://doi.org/10.1007/s00018-016-2391-y

42. Salinas D, Haggie PM, Thiagarajah JR, Song Y, Rosbe K, Finkbeiner WE, Nielson DW, Verkman AS (2005) Submucosal gland dysfunction as a primary defect in cystic fibrosis. FASEB J 19:431-433. https://doi.org/10. 1096/f.04-2879fje

43. Schultz A, Puvvadi R, Borisov SM, Shaw NC, Klimant I, Berry LJ, Montgomery ST, Nguyen T, Kreda SM, Kicic A, Noble PB, Button B, Stick SM (2017) Airway surface liquid $\mathrm{pH}$ is not acidic in children with cystic fibrosis. Nat Commun 8:1409. https://doi.org/10.1038/s41467-017-00532-5

44. Shamsuddin AK, Quinton PM (2012) Surface fluid absorption and secretion in small airways. J Physiol 590:3561-3574. https://doi.org/10.1113/ jphysiol.2012.230714

45. Shamsuddin AKM, Quinton PM (2019) Concurrent absorption and secretion of airway surface liquids and bicarbonate secretion in human bronchioles. Am J Physiol Lung Cell Mol Physiol 316:953-960. https://doi. org/10.1152/ajplung.00545.2018

46. Sheppard MN (1995) The pathology of cystic fibrosis. In: Hodson ME, Geddes DM (eds) Cystic fibrosis. Chapman \& Hall Medical, London, pp 131-149

47. Smith JJ, Travis SM, Greenberg EP, Welsh MJ (1996) Cystic fibrosis airway epithelia fail to kill bacteria because of abnormal airway surface fluid. Cell 8:229-236. https://doi.org/10.1016/s0092-8674(00)81099-5

48. Thomas JA, Buchsbaum RN, Zimniak A, Racker E (1979) Intracellular pH measurements in Ehrlich ascites tumor cells utilizing spectroscopic probes generated in situ. Biochemistry 18:2210-2218. https://doi.org/10. 1021/bi00578a012

49. Urbach V, Hélix N, Renaudon B, Harvey BJ (2002) Cellular mechanisms for apical ATP effects on intracellular pH in human bronchial epithelium. J Physiol 543:13-21. https://doi.org/10.1113/jphysiol.2001.015180

50. Weibel ER (1963) Morphometry of the Human Lung. Springer, Berlin. https://doi.org/10.1007/978-3-642-87553-3

51. Xu H, Ghishan FK, Kiela PR (2018) SLC9 gene family: function, expression, and regulation. Compr Physiol 8:555-583. https://doi.org/10.1002/cphy. C170027

52. Zajac M, Dreano E, Edwards A, Planelles G, Sermet-Gaudelus I (2021) Airway surface liquid $\mathrm{pH}$ regulation in airway epithelium: current understandings and gaps in knowledge. Int J Mol Sci 22:3384. https://doi.org/ 10.3390/ijms22073384

53. Zeiher BG, Eichwald E, Zabner J, Smith JJ, Puga AP, McCray PB Jr, Capecchi MR, Welsh MJ, Thomas KR (1995) A mouse model for the delta F508 allele of cystic fibrosis. J Clin Invest 96:2051-2064. https://doi.org/10.1172/JCI11 8253

\section{Publisher's Note}

Springer Nature remains neutral with regard to jurisdictional claims in published maps and institutional affiliations.

$$
\begin{aligned}
& \text { Ready to submit your research? Choose BMC and benefit from: } \\
& \text { - fast, convenient online submission } \\
& \text { - thorough peer review by experienced researchers in your field } \\
& \text { - rapid publication on acceptance } \\
& \text { - support for research data, including large and complex data types } \\
& \text { - gold Open Access which fosters wider collaboration and increased citations } \\
& \text { - maximum visibility for your research: over } 100 \mathrm{M} \text { website views per year }
\end{aligned}
$$

At BMC, research is always in progress.

Learn more biomedcentral.com/submissions 